Cornell University Law School Scholarship@Cornell Law: A Digital Repository

Spring 2002

\title{
Knowledge at Work: Disputes over the Ownership of Human Capital in the Changing Workplace
}

Katherine V.W. Stone

Cornell Law School

Follow this and additional works at: https://scholarship.law.cornell.edu/facpub

Part of the Contracts Commons, Labor and Employment Law Commons, and the Law and Economics Commons

\section{Recommended Citation}

Stone, Katherine V.W., "Knowledge at Work: Disputes over the Ownership of Human Capital in the Changing Workplace" (2002). Cornell Law Faculty Publications. 1609.

https://scholarship.law.cornell.edu/facpub/1609 


\title{
Knowledge at Work: Disputes Over the Ownership of Human Capital in the Changing Workplace*
}

\author{
KATHERINE V.W. STONE
}

\section{INTRODUCTION}

While it may be true that "knowledge is power," in the current era it is perhaps more accurate to say that knowledge is value-economic value. In this information age, the possession of individual knowledge, expertise, and skill are the primary sources of institutional and individual advancement. Most firms believe that the knowledge possessed by their employees is their major asset and their primary source of competitive advantage. ${ }^{1}$ In the words of Fortune magazine editor, Thomas Stewart, "Information and knowledge are the thermonuclear competitive weapons of our time."2

Today's firms compete fiercely in "talent wars" to recruit the best applicants. They vie for the top talent by offering learning opportunities, lifestyle perks, and performance incentive compensation. For example,

"Portions of this Article appeared in Katherine V.W. Stone, The New Psychological Contract: Implications of the Changing Workplace for Labor and Employment Law, 48 UCLA L. REv. 519 (2001).

Professor of Law, Cornell Law School, and Anne E. Estabrook Professor of Dispute Resolution, Cornell School of Industrial and Labor Relations.

${ }^{1}$ See, e.g., Dale Neef, Rethinking Economics in the Knowledge-Based Economy, in DALE NEEF, G. ANTHONY SIESFELD \& JACQUELYN CEFOLA, THE ECONOMIC IMPACT OF KNOWLEDGE 3; 4 (Butterworth, 1998).

Whereas in the past most value in manufactured goods came from raw materials, plant and labor costs, today intangible inputs that are dependent upon employee knowledge and skills-creativity and design proficiency, customer relationships and goodwill, innovative marketing and sales techniques-account for an average of [seventy] percent of the value of automobiles and an incredible [eighty-five] percent of the value of high-technology goods such as microchips or CDs. Today, and in the future, it is "brain" and not "brawn" that is the key to economic growth.

Id. Bruce A. Lehman, Intellectual Property: America's Competitive Advantage in the 21st Century, 31 COLUM. J. WORLD BUS. 6, 10 (Spring 1996) ("Both new corporations and restructured corporations and industries are finding that one of their most valuable assets is their intellectual property.").

2 Thomas A. SteWART, INTEllectual Capital: The New Wealth of ORganizations, at ixx (1999). 
management consultant Bruce Tulgan advises firms that to attract and retain valued employees, they should permit people to customize their jobs to suit their own ambitions and lifestyles. ${ }^{3}$ Firms should let their employees select their own work tasks, work location, and schedule. ${ }^{4}$ In a similar vein, Rosabeth Moss Kanter, a management theorist, advises firms that to attract a committed workforce they need to make employees feel welcome and valued by creating a culture of respect and trust. ${ }^{s}$ She suggests giving new employees gifts to welcome them into the workplace community, providing buddies and mentors to cement their bond, staging periodic formal and informal recognition ceremonies to foster positive feelings, and providing family-friendly schedules to accommodate their private lives. ${ }^{6}$

In addition to altering recruitment practices, firms are actively reorganizing their human resource practices in order to utilize and enhance the talents and intellectual capacities of their incumbent employees. ${ }^{7}$ Firms have departed from the labor relations practices of the past, and have constructed a radically new type of workplace, one that is dedicated to expanding and deploying the human capital of their employees rather than to maintaining hierarchy and control. In their quest for quality and flexibility, employers no longer value long-term attachment. Thus, they have replaced their former implicit promises of long-term job security and hierarchical progression through identifiable job ladders with promises of training, upskilling, and networking opportunities.

As firms and employees have come to recognize the enormous value of employee human capital, disputes over ownership of human capital have increased. ${ }^{3}$ Such conflicts may well be endemic to the information-based workplace, in which the unique nature of human capital defies simple legal categorization. Employees bring knowledge and capabilities to their jobs and expect that their jobs will further increase their human capital, whether by providing experience and learning on the job, or by providing more formal training opportunities. Employees see the growth of their human capital and the enhancement of their labor market opportunities as one of the benefits of the job. Jobs are often evaluated and selected on the basis of whether and how much opportunity for learning and skill enhancement is provided. Accordingly, employees assume that the skills and knowledge they acquire on a particular job "belong" to them in the sense that they take these with them when they depart.

3 BRUCE TUlgan, WINNING THE TALENT WARS 155-57 (2001).

${ }^{4}$ Id. at 161-76.

5 ROSABETH MOSS KANTER, EVOLVE!: SUCCEEDING IN THE DIGITAL CULTURE OF TOMORROW 211-14 (2001).

${ }^{6}$ ld.

7 See infra Part II.B.

${ }^{8}$ See infra fig.2. 
Employers, on the other hand, believe that if they have imparted valuable skills or knowledge to their employees, they should "own" that human capital in the sense of being able to ensure that it is utilized on their firm's behalf. While they cannot compel an employee to remain with their firm, employers can, and do, attempt to prevent former employees from using knowledge obtained in their employ on behalf of a competitor. Thus, employers increasingly seek to impose and enforce post-employment restraints. When employees depart, employers often seek judicial enforcement of covenants not to compete or judicial protection for their trade secrets.

The conflicting perspectives of employees and employers about the ownership of human capital has generated an increasing number of legal disputes. More and more, employers are requiring employees to sign covenants not to compete and covenants not to disclose confidential information at the outset of an employment relationship. ' Increasingly, employers are suing their former employees at the end of an employment relationship, seeking to enjoin them from taking knowledge acquired on the job for use on behalf of a competitor. In the past decade, there has been an exponential increase in the volume of lawsuits between employers and former employees involving covenants not to compete and the ownership of information and knowledge. ${ }^{10}$ Indeed, disputes over ownership of human capital are becoming some of the most important and frequently litigated issues in the employment law field. ${ }^{11}$

The law of post-employment restraints has been described as a "seavast and vacillating, overlapping and bewildering. One can fish out of it any kind of strange support for anything, if he lives so long."12 In this primal soup, one finds a murky intertwine of conflicting interests: employee interest in job mobility; employer interest in protecting their business secrets; society's interest in a free and competitive labor market; and judicial interest in enforcing contracts. While the case law on restrictive covenants

${ }^{9}$ See Phillip J. Closius \& Henry M. Schaffer, Involuntary Nonservitude: The Current Judicial Enforcement of Employee Covenants Not to Compete-A Proposal for Reform, 57 S. CAL. L. REv. 531, 532 (1984) (noting an increased use of covenants not to compete in employment contracts); Peter J. Whitmore, A Statistical Analysis of Noncompetition Clauses in Employment Contracts, 15 J. CoRP. L. 483,489 (1990) (noting that "noncompetition covenants continue to be used with ever-increasing frequency").

${ }^{10}$ Suellen Lowry, Note, Inevitable Disclosure Trade Secret Disputes: Dissolutions of Concurrent Property Interests, 40 STAN. L. REV. 519, 519 (1988) (noting the dramatic increase in trade secret litigation); Tracy L. Staidl, The Enforceability of Noncompetition Agreements When Employment Is AtWill: Reformulating the Analysis, 2 EMPLOYEE RTS. \& EMP. POL'Y J. 95, 118 (1998) (describing how post-employment noncompetition agreements have become typical additions to employment contracts and an increasingly frequent basis for litigation).

"See infra fig.2.

12 Arthur Murray Dance Studios of Cleveland, Inc. v. Witter, 105 N.E.2d 685, 687 (Ohio Ct. C.P. 1952). 
has been tangled in the past, today many courts, legislatures, and commentators are confronting post-employment constraint issues anew, and many new approaches have been advocated. ${ }^{13}$ No uniform consensus has yet emerged.

The increased number of disputes over post-employment restraints is the result of two developments: (1) the recognition of the central value of employee human capital in the production process, and (2) the fact that changing work practices have caused a decline in job security and a corresponding increase in employee mobility. Both of these developments are functions of the new human resource practices that are spreading through the U.S. economy. These new practices embody new sets of expectations and understandings about the employment relationship that are relevant to a court's evaluation of post-employment restraints. It is necessary to understand the advent of the new organization of work and the implicit and explicit understandings that it embodies, in order to develop an approach to the question, "Who owns employee human capital?"

This Article explores the current state of the law of post-employment restraints from the vantage point of the implicit and explicit promises that make up the new employment relationship. It contends that it is not possible to determine the appropriate scope for judicial enforcement of postemployment restraints without an understanding of the nature of the new employment relationship. It argues that courts should inquire into the terms - tacit and explicit—of the new employment contract in determining whether to enforce post-employment restraints. In particular, this Article contends that the terms of the new employment contract-specifically, the promise of training and networking opportunities-are undermined when courts are expansive in their approach to enforcement of restrictive covenants and the definitions of trade secrets.

The Article proceeds as follows: Part II describes the nature of the new employment relationship. Part III discusses the evolving law of postemployment restraints, with specific focus on covenants not to compete and trade secrets. It shows that courts have become increasingly expansive in their approaches to post-employment restraints, and demonstrates that

${ }^{13}$ See Outsource Int'l, Inc. v. Barton, 192 F.3d 662, 670 (7th Cir. 1999) (Posner, J., dissenting) (advocating enforcement of all post-employment covenants so long as there was contractual consent, and no fraud, duress or unconscionability); see generally Rachel Amow-Richman, Bargaining for Loyalty in the Information Age, 80 OR. L. REV. (forthcoming Feb. 2002) (advocating that courts adopt a formation-based approach to non-competition agreements); Gillian Lester, Restrictive Covenants, Employee Training, and the Limits of Transaction-Cost Analysis, 76 IND. L.J. 49 (2001) (questioning usefulness of transaction cost economics to decide when to enforce restrictive covenants); Paul $\mathrm{H}$. Rubin \& Peter Shedd, Human Capital and Covenants Not to Compete, 10 J. LEG. STUD. 93 (1981) (applying human capital theory to non-competition covenants) ERIC A. POSNER \& GEORGE G. TRIANtis, Covenants Not to COMPETE From an INCOMPLETE Contracts PERSPECTIVE (Chicago Law \& Econ., Working Paper No. 137, 2001) (comparing enforcement of covenants not to compete to enforcement of employment contracts by liquidated damages and specific performance). 
such approaches are directly contrary to the terms of the new employment relationship. It argues that courts should take the terms of the new employment relationship into account when deciding when to enforce covenants not to compete and how to define employers' trade secrets. Part IV addresses the more general question of the role of mutual understandings and implicit contracts in employment regulation. It presents examples from legal history to argue that courts can and should take the parties' implicit understandings into account when devising regimes of employment regulation.

\section{The Changing NATURE OF THE EMPLOYMENT RELATIONSHIP}

\section{A. The Labor Relations System of the Past}

In the past, most large corporations organized their workforces into what has been termed "internal labor markets."14 In internal labor markets, jobs were arranged into hierarchical ladders; each job provided the training for the job on the next rung up. Employers who maintained internal labor markets hired only at the entry level and then utilized internal promotions to fill all of the higher rungs. Employers wanted employees to stay a long time, so they gave them implicit promises of long-term employment and of orderly and predictable patterns of promotion. Consistent with internal labor market job structures, employers structured pay and benefit systems so that wages and benefits rose as length of service increased..$^{15}$ Employers also relied upon job ladders to provide employees with the requisite firmspecific training for the jobs higher up. The job ladders tended to be accompanied by seniority systems and narrow job classifications to define promotion opportunities.

Our labor and employment laws have been constructed on the basis of a view of the employment relationship that saw the employment relationship as a long-term relationship between a firm and an employee in which the employer gave the worker an implicit promise of lifetime job security and opportunities for promotion along clearly-defined job ladders. This paradigm, or template, was never universal in actuality, and in particular, it

\footnotetext{
14 See generally PETER B. DOERINGER \& MICHAEL J. PIORE, INTERNAL LABOR MARKETS AND MANPOWER ANALYSIS (1971) (discussing the reshaping of the internal labor market scheme); Katherine Stone, The Origins of Job Structures in the Steel Industry, in LABOR MARKET SEGMENTATION (Richard Edwards et al. eds., 1975) (tracing the development of internal labor markets in the steel industry); see also ClAUDIA DALE GOLDIN, UNDERSTANDING THE GENDER GAP: AN ECONOMIC HISTORY OF AMERICAN WOMEN $247 \mathrm{n} .38$ (1990) (reviewing the economic literature on internal labor market institutions).

${ }^{15}$ See Katherine Van Wezel Stone, Policing Employment Contracts Within the Nexus-ofContracts Firm, 43 U. TORONTO L.J. 353, 363-69 (1993) (discussing the implicit contract model of the employment relationship).
} 
did not pertain to the labor market experiences of most women.

In recent years, employers have dismantled their internal labor market job structures and abandoned the implicit promises that went along with them. ${ }^{16}$ In their place, employers are creating new types of employment relationships that do not depend upon, or encourage, longevity. They do this to give themselves flexibility to cross-utilize employees and to make quick adjustments in production methods as they confront increasingly competitive product markets. Work has thus become contingent, not only in the sense that it is formally defined as short-term or episodic, but also in the sense that the attachment between the firm and the worker has been weakened. Some scholars have emphasized the increase in temporary, part-time, and other forms of atypical work to describe the increased contingency in the employment relationship. ${ }^{17}$ While these types of employment have indeed been growing rapidly, they remain a minuscule portion of the workforce. ${ }^{18}$ The more significant change in labor relations concerns the change in the nature of regular, full-time work. The "recasualization of work" has reportedly become a fact of life all along the employment spectrum, from blue-collar workers to high-end professionals and managers. ${ }^{19}$

The changes in the employment relationship are reflected in the government employment data on job tenure and turnover. According to the Bureau of Labor Statistics, between 1983 and 1998 there was a significant decline in the percentage of men who have been with their current employer for ten years or more. ${ }^{20}$ For men ages forty to forty-four, those with job tenure of ten years or more declined from fifty-one percent in 1983, to thirty-nine percent in $1998 .^{21}$ Similar large declines occurred for men in every age group over forty-five. Men between age fifty-five and sixty-four

${ }^{16}$ See, e.g., The Future of Work: Career Evolution, EconOMIST, Jan. 29-Feb. 4, 2000, at 89 (commenting that the future structure of the employment contract remains uncertain); see also PETER F. DRUCKER, MANAGING IN A TIME OF GREAT CHANGE (1995) (highlighting changes that have occurred regarding the employment relationship and suggesting management methods for the future); ROSABETH MOSS KANTER, ON THE FRONTIERS OF MANAGEMENT 190 (1997) (discussing the new agenda regarding human resources); RICHARD SENNETT, THE CORROSION OF CHARACTER: THE PERSONAL CONSEQUENCES OF WORK IN THE NEW CAPITALISM 23 (1998) (highlighting changes in the modern institutional structure of employment).

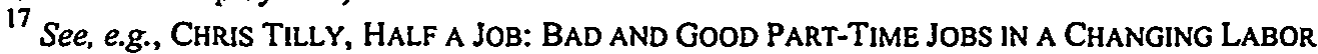
MAERKET 13-15 (1996); Gillian Lester, Careers and Contingency, 51 STAN. L. REV. 73 (1998).

${ }^{18}$ See Bureau of Labor Statistics, U.S. Dep't of Labor, Contingent and Alternative Employment Arrangements (Dec. 21, 1999) (presenting labor force statistics from the Current Population Survey) [hereinafter Contingent Employment], at http://stats.bls.gov/news.release/conemp.nws.htm (last visited Jan. 23, 2002) (on file with the Connecticut Law Review); Sharon R. Cohany, Workers in Alternative Employment Arrangements: A Second Look, 121 MONTHLY LAB. REV. 3, 3-5 (1998).

${ }^{19}$ DRUCKER, supra note 16, at 66-67.

${ }^{20}$ BuREau Of LABOR STATistics, U.S. DEP'T OF LABOR, EMPlOYEe TENURE in 2000 (Aug. 29, 2000) [hereinafter EMPLOYEE TENURE], at http://www.bls.gov/bls/news.release/tenure.nro.htm (on file with the Connecticut Law Review).

${ }^{21}$ Id. 
have also seen their median years on their current job decline from 15.3 years to 11.2 years between 1983 and $1998 .{ }^{22}$ For men ages forty-five to fifty-four, the decline was from 12.8 to 9.4 years. $^{23}$ These are dramatic changes.

In 1995, economist Henry Farber analyzed the CPS job tenure data and concluded that between 1973 and 1993 there was a "substantial decline in the population-based median [job tenure] for males."24 Farber wrote again about job tenure in 1998, using the BLS's Displaced Worker Survey, and found that there was an increased job loss in the 1990s. At that time he wrote:

What is most striking is that the job loss rate increased dramatically in the 1993-95 period despite the sustained economic expansion accompanied by a further decline in the unemployment rate to $5.6 \%$ in 1995 . This is evidence consistent with the view that there has been a secular decline in job security. ${ }^{25}$

In 1999, economists David Jaeger and Anne Huff Stevens also analyzed both the Current Population Survey and the Panel Study of Income Dynamics, and concluded that "both data sets show an increase in the fraction of men with less than ten years of tenure starting in the late 1980s."26

Not all groups of workers experienced dramatic declines in their job tenure in the 1990s. Farber found that the decline in men's job tenure occurred primarily within the group of less well-educated men-those who had a high school degree or less. ${ }^{27}$ College educated men also experienced a decline in their job tenure in the 1990s, but the decline of blue-collar job tenure remained far more pronounced. Furthermore, women did not experience a marked decline in their job tenure, and in some cases they even experienced a modest increase. ${ }^{28}$ Thus, it is clear that the most significant decline in job tenure occurred amongst those workers who enjoyed the de facto job security and long-term employment arrangements of the internal labor market job structures-i.e., among blue-collar males.

The job tenure data suggests that the internal labor market description of the world of work that underlies our system of employment regulation is

22 Id.

23 Id.

${ }^{24}$ HeNRY S. FARBer, ARE LIFETIME JOBS Disappearing? JOB DURATION IN THE UNITED STATES: 1973-1993 (NBER Working Paper No. 5014, 1995).

${ }^{25}$ Henry S. Farber, Has the Rate of Job Loss Increased in the Nineties?, Proc. 50th Ann Meeting Indus. Rel. Res. Ass'n 88 (1998).

${ }^{26}$ David Jaeger \& Anne Huff Stevens, Is Job Security in the United States Falling?, 17 J. LAB. ECON. SI (1999). Other studies have reached similar conclusions. See, e.g., Robert G. Valletta, Declining Job Security, 17 J. LAB. ECON. S170 (1999) (citing numerous studies).

${ }^{27}$ FARBER, supra note 24.

${ }^{28}$ Id.. 
no longer an apt description of reality, even for those to whom it applied. Those blue-collar men who were in the long-term employment relationships in the past and have seen their job tenure decline were the paradigmatic "workers" as well as the beneficiaries of the old labor system. They comprised approximately twenty-five percent of the adult population as recently as 1990 . Women have not traditionally been part of the long-term employment system, so that the increases in their the overall job tenure rates-as measured by the percentages of women working for their employer for ten years or more-remains significantly lower than men. ${ }^{29}$

The job tenure data is only one indicator of the decline in internal labor markets, and not necessarily the best one. What characterized internal labor markets, from an employee's point of view, was the expectation of long-term job security. Job tenure data is, at best, a proxy for this subjective understanding. If the prevalence of employment relationships that embody such an implicit understanding is declining, that fact might or might not show up in job tenure data. A person who works at McDonald's for twenty years, always knowing that they might be fired at the end of the week, has a different understanding of their employment contract-a different "psychological contract"- - than a person who worked for General Motors in the 1950s. Job tenure data, while suggestive of a trend, is a posthoc account of employee labor market experience, and does not tell the whole story about changes in employment relationships. For that reason, I believe it is necessary to supplement the simple medians with journalistic accounts and academic studies by those in other disciplines such as organizational behavior and the sociology of work.

There are many accounts of the contemporary labor market by journalists, scholars, and corporate executives. These informants report that there is a fundamental change in the implicit, psychological contract under which most Americans are now employed. For example, the sociologist Richard Sennett interviewed a number of younger employees about their experiences in the labor market. He reports:

The most tangible sign of that change might be the motto "No long term." In work, the traditional career progressing step-by-step through the corridors of one or two institutions is withering; so is the deployment of a single set of skills through the course of a working life. ${ }^{30}$

Sennett also quotes an executive of AT\&T, who told him: "In AT\&T we have to promote the whole concept of the work force being contingent, though most of the contingent workers are inside our walls. 'Jobs' are be1998).

${ }^{29}$ See Francine D. BlaU et al., THE ECONOMics OF WOMEN, MEN AND WORK $113-15$ (3d ed.

${ }^{30}$ SENNETT, supra note 16 , at 22. 
ing replaced by 'projects' and 'fields of work."'31

The same sentiment was expressed eloquently by Jack Welch, the miracle-maker CEO of General Electric Company ("GE"), who was asked by the Harvard Business Review in 1989, "What is GE's psychological contract with its people?"'32 Welch replied:

Like many other large companies in the United States, Europe, and Japan, GE has had an implicit psychological contract based on perceived lifetime employment. People were rarely dismissed except for cause or severe business downturns, like in Aerospace after Vietnam. This produced a paternal, feudal, fuzzy kind of loyalty. You put in your time, worked hard, and the company took care of you for life.

That kind of loyalty tends to focus people inward. But given today's environment, people's emotional energy must be focused outward on a competitive world where no business is a safe haven for employment unless it is winning in the marketplace. The psychological contract has to change..$^{33}$

Another well-known management theorist, Peter Drucker, stated bluntly: "There is no such thing as 'lifetime employment' anymore-such as was the rule in big U.S. or European companies only a few years ago."34

Why are corporations restructuring their employment practices? Work practices are being adjusted to production requirements. As firms are forced into a more competitive environment through increased trade and global competition, they have to pay more attention to short-term cost reductions. In addition, the takeover battles in the market for corporate control force firm managers to be responsive to short-term change in revenues and demand. Part of this responsiveness involves just-in-time production, just-in-time product design, and just-in-time workers.

\section{B. The Nature of the New Workplace}

\section{The New Psychological Contract}

The change in the nature of employment involves more than merely ex-post changes in job tenure. Rather, the ex-post changes in job tenure are concrete manifestations of the more subtle but dramatic changes that have been occurring in the nature of the employment relationship itself. Organizational theorists have developed the concept of the "psychological

31 Id.

${ }^{32}$ Noel Tichy \& Ram Charan, Speed, Simplicity, Self-Confidence: An Interview with Jack Welch, HARV, BUS. REV., Sept.-Oct. 1989, at 112, 120.

${ }^{33}$ Id.

${ }^{34}$ DRUCKER, supra note 16 , at 71. 
contract" to characterize the implicit and explicit understandings that employees and employers bring to their jobs. In the parlance of that field, there has been a change in the psychological contract.

The term "psychological contract," as used by organizational theorists, refers to an individual's beliefs about the terms of his or her employment contract. ${ }^{35}$ The term refers to an employee's perceptions of the terms of a reciprocal exchange. ${ }^{36}$ The reciprocal nature of the belief distinguishes a psychological contract from mere expectations, which reflect the employee's hopes and aspirations, but not the belief in mutual obligation. ${ }^{37}$ When expectations are not met, an employee is disappointed; when a psychological contract is breached, the employee feels wronged. ${ }^{38}$ Researchers find that "[f]ailure to honor a contract creates a sense of wrongdoing, deception and betrayal with pervasive implications for the employment relationship." 39

Academic interest in the notion of psychological contracts developed during the period in which middle management in large American corporations were the victims of large-scale downsizing and corporate restructuring. In studying those left standing after massive layoffs in their firms-a group referred to by the evocative term "layoff survivors," as well as those who lost their jobs but were later reemployed at new firms, termed "expatriate managers"- organizational sociologists theorized that these employees' intense sense of unfairness and anger was a result of the fact that the changes in their employment were inconsistent with their tacit assumptions about the terms of their employment contracts. ${ }^{40}$ The term psychological contract is useful to theorists of organizational behavior because it captures both the fact that parties bring expectations of reciprocal obligation to the

${ }^{35}$ Sandra L. Robinson \& Denise M. Rousseau, Violating the Psychological Contract: Not the Exception But the Norm, 15 J. ORG. BEHAV. 245, 246 (1994).

${ }^{36}$ For terminological clarity, scholar Denise Rousseau contrasts the term psychological contract with the term implicit contract, in which the former describes the employees' subjective beliefs about the terms of the employment relationship and the latter describes a third party's assessment of the relationship. Denise M. Rousseau, The 'Problem' of the Psychological Contract Considered, $19 \mathrm{~J}$. ORG. BEHAV. 665, 666-68 (1998). They can both refer to the same contract, but from a different perspective. See id.

${ }^{37}$ See Robinson \& Rousseau, supra note 35, at 246.

38 See id. at 247.

39 Id.

${ }^{40}$ See generally Neil Anderson \& René Schalk, The Psychological Contract in Retrospect and Prospect, 19 J. ORG. BEHAV. 637, 643-44 (1998) (summarizing studies on the impact on employees of employer breach of psychological contracts). On the term "layoff survivors" see, for example, Marjorie Armstrong-Stassen, Coping with Transition: A Study of Layoff Surviors, 15 J. ORG. BEHAV. 597-621 (1994); Joel Brockner, Tom R. Tyler \& Rochelle Cooper-Schneider, The Influence of Prior Commitment to an Institution on Reactions to Perceived Unfairness: The Higher They Are, the Harder They Fall, 37 ADMIN. SCIEN. Q. 241-61 (1992); Kelly A. Mollica \& Rocki-Lee DeWitt, When Others Retire Early What About Me?, 43 ACAD. MGMT. J. 1068-75 (2000). 
employment relationship, and it accounts for the intense sense of injustice that can result when these expectations are not met.

For present purposes, the important fact of the psychological contract is that it is undergoing a profound transformation. According to organizational theorists Maurice Cavanaugh and Raymond Noe:

[Under] the old psychological contract, the employer was seen as a caretaker for the employee. Employees who were good performers were virtually guaranteed a job by their employer until retirement, the employer helped employees plan their careers and provided promotions to ensure career development, and employees were loyal and committed to the job and the organization. In the new psychological contract, both employees and employers have lower expectations for long-term employment, employees are responsible for their own career development, and commitment to the work has replaced commitment to the job and organization. ${ }^{41}$

The academic literature about the new psychological contract tries to characterize the new set of expectations that managers impart to their employees, expectations not of long-term job security and continuous promotion up a job ladder, but of something else. Just what are the new terms can be found in the literature about competency-based organizations, total quality management, and other high involvement work practices that define the new workplace as it is imagined and currently being constructed by management and management consultants. ${ }^{42}$

It is important to understand the terms of the new psychological contract in order to assess the propriety of post-employment restraints. In order to understand these terms, it is necessary to introduce two additional new concepts from the organizational behavior literature-the concept of the boundaryless career and the concept of organizational citizenship behavior.

\section{The Notion of the Boundaryless Career}

A boundaryless career is a career that does not depend upon traditional notions of advancement within a single hierarchical organization. It includes an employee who moves frequently across the borders of different employers, such as Silicon Valley technicians, and one whose career draws its validation and marketability from outside the present employer. It also

${ }^{41}$ Marcie A. Cavanaugh \& Raymond A. Noe, Antecedents and Consequences of Relational Components of the New Psychological Contract, 20 J. ORG.. BEHAV. 323, 324 (1999) (citations omitted).

42 See generally Mark Roehling et al., The Nature of the New Employment Relationship(s): A Content Analysis of the Practitioner and Academic Literatures, 39 HUM. RESOURCE MGMT. (4): 30520 (1998) (deriving primary attributes of the new employment relationship from an extensive literature survey). 
refers to changes within organizations, in which individuals are expected to move laterally, without constraint from traditional hierarchical career lattices. ${ }^{43}$ A boundaryless career has been defined as "a career which unfolds unconstrained by clear boundaries around job activities, by fixed sequences of such activities, or by attachment to one organization."44

The advent of boundaryless careers is said to correspond to the growth in joint ventures, outsourcing, and other forms of network production that permit, and sometimes even encourage, mobility among related enterprises. ${ }^{45}$ It is also related to change within firms, where departmental boundaries and job definitions are being replaced with broadly defined bands. ${ }^{46}$ Whereas previously, careers were understood to unfold in structured ways, either with internal labor markets or along fixed lattices on organizational flow-charts, recent research on careers has found fluidity. One scholar writes, "Inside firms in the United States, decentralization and increasing emphasis on cross-functional coordination and teams have blurred previously rigid departmental boundaries. Many American employers have moved to more general job descriptions, emphasizing key values, rather than precise, predetermined duties."47

The advent of the boundaryless career is a major departure from the internal labor markets of the past. Instead of encountering job ladders along which employees advance within stable, long-term employment settings, today's employees are confronted with possibilities for lateral mobility among and within firms, with no set path, no established expectations, and no tacit promises of job security. Employees are expected to chart their own path, face their own fortunes, and manage their own careers in a boundaryless workplace.

\section{The Concept of Organizational Citizenship Behavior}

Firms need to motivate employees to perform efficiently. However, efficiency is not sufficient in today's world. Firms need more than merely competent and predictable role performance; they also need "spontaneous and innovative activity that goes beyond role requirements."48 Firms want employees to take an entrepreneurial approach to their jobs. They want to induce employees to exercise creativity on behalf of the firm. They want

${ }^{43}$ Id.

44 Anne S. Miner \& David F. Robinson, Organizational and Population Level Learning As Engines for Career Transitions, 15 J. ORG. BEHAV. 345, 347 (1994).

${ }^{45}$ See DRUCKER, supra note 16, at 66-67.

${ }^{46}$ See id. at 345; see also THOMAS O. DAVENPORT, HUMAN CAPITAL: WHAT IT IS AND WHY PEOPLE INVEST IN IT 152-56 (1999) (urging firms to create "communities of practice").

47 Miner \& Robinson, supra note 38, at 347 (citations omitted).

48 John R. Deckop et al., Getting More Than You Pay For: Organizational Citizenship Behavior and Pay for Performance Plans, 42 ACAD. MGMT. J. 420, 420 (1999). 
employees to innovate, to pitch in, to behave like owners. ${ }^{49}$ Current management theories dictate that firms give employees discretion, but managers want to ensure that this discretion is exercised on behalf of the firm. Thus, managers want to elicit behavior that goes beyond specific rules and job demands, and gives the firm something extra. Organizational theorists characterize this something extra as organizational citizenship behavior ("OCB"). ${ }^{50}$

$O C B$ is defined as discretionary behavior that goes beyond the requirements of specific role definitions and that is not rewarded in the formal reward structure of the firm. ${ }^{51}$ It does not mean excellence in role performance, but rather performance that goes beyond formal role requirements to further organizational goals. OCB has been found to be one of the most significant elements in organizational effectiveness. As such, much of current human resource policy is designed to encourage OCB. ${ }^{52}$ Yet, while today's human resource practices are designed to elicit OCB, they attempt to do so without making promises of job security. That is, the goal of today's management is to engender commitment without loyalty. ${ }^{53}$

\section{The Terms of the New Employment Relationship}

Today's managers face a fundamental paradox: Firms need to motivate employees to provide commitment to quality, productivity, and efficiency, while at the same time, they are dismantling the job security and job ladders that have given employees a stake in the well-being of their firms for the past 100 years. In the past, internal labor markets were adopted by firms to solve problems of employee motivation, encourage skill acquisition, and discourage employee oppositional behavior. In the new era, firms need to find other means to accomplish these goals.

Contemporary management theory is dedicated to devising organizational structures that embody flexibility, promote skill development, and foster organizational citizenship behavior-all at the same time. The management systems of competency-based organizations and total quality management ("TQM") are two leading examples of comprehensive pro-

49 See, e.g., DAVENPORT, supra note 46, at 3-8 (advocating that managers should view employees as investors in human capital because they bring "ingenuity, creativity, and initiative" to their companies).

${ }^{50}$ See Dennis W. Organ, Organizational Citizenship Behavior: THE GoOd Soldier SYN. DROME 4-5 (1988).

51 Id.

52 Id. at 105; Ann C. Smith et al., Organizational Citizenship Behavior: Its Nature and Antecedents, 68 J. APPLIED PSYCHOL. 653, 653-63 (1983). Organizational effectiveness is comprised of features such as efficiency, ability to attract valuable resources, good will, external image, reputation, innovativeness, and adaptability. See generally ORGAN, supra note 50, at 6-7.

53 See Peter Cappelli, The New Deal at Work: Managing the Market-Driven Work FORCE 217 (1999). 
posals for restructuring the workplace. Advocates of competency-based organization emphasize skill development by insisting that employees be paid for the skills they have, rather than according to lock-step job evaluation formulas. ${ }^{54}$ They argue that skill-based pay will give employees an incentive to acquire new skills, and will make it incumbent upon employers to provide training and career development opportunities. ${ }^{55}$ Advocates of TQM, meanwhile, counsel firms to involve every employee, at every level, in continuous product and service improvement. Some of the specific recommendations of TQM are to provide continuous training and opportunities for individual improvement, and to give workers direct contact with customers, external suppliers, and others who do business with the firm. ${ }^{56}$ Both competency-based organization theory and TQM are methods for increasing employee knowledge and inducing employees to use that knowledge on behalf of the firm.

Management theorist Rosabeth Moss Kanter acknowledges that the new high-commitment management models are colliding with the "job insecurity reality" found in American corporations. ${ }^{57}$ She resolves the paradox by advocating that firms offer "employability security" instead of employment security. She says firms should provide lifetime training and retraining opportunities. ${ }^{58}$ She claims that this will enable firms to attract high-caliber talent and give those employees who are downsized other opportunities. ${ }^{59}$ She also proposes a model employability contract, by which the firm promises to upgrade worker skills and help provide new job opportunities should those at the firm disappear..$^{60}$

54 See Edward E. Lawler III, The Ultimate advantage: Creating the highINVOLVEMENT ORGANIZATION 156 (1992).

${ }^{55}$ See generally id. at 144-56 (noting that such a system encourages employers to determine what skills are beneficial to the company and which employees can be taught those skills); Katherine V.W. Stone, The New Psychological Contract: Implications of the Changing Workplace for Labor and Employment Law, 48 UCLA L. REV. 519, 563 (2001) (noting that if employees are paid based on their skill level, they will be more motivated to develop new skills).

${ }^{56}$ See ERIC E. ANSCHUTZ, TQM AMERICA: HOW AMERICA'S MOST SUCCESSFUL COMPANIES PROFIT FROM TOTAL QUALITY MANAGEMENT 1.4 (1995); see also JOSHUA G. ROSETT \& RICHARD N. ROSETT, CHARACTERISTICS OF TQM: EVIDENCE FROM THE RIT/USA TODAY QUALITY CUP COMPETITION 16-17 (Nat'l Bureau of Econ. Research, Working Paper No. 7241, 1999) (discussing training in team-based problem solving). See generally Stone, supra note 50, at 565-68.

${ }^{57}$ KANTER, supra note 16 , at 190.

${ }^{58}$ Id. at 192.

59 Id.

${ }^{60}$ Id. at 194. In her model employability security contract, Kanter recommends that companies make a written pledge that states, inter alia:

Although we cannot guarantee tenure in any particular job or even future employment, we will work to ensure that all our people are fully employable.... We promise to:

-Recruit for the potential to increase in competence, not simply for narrow skills to fill today's slots.

-Offer ample learning opportunities, from formal training to lunchtime semi- 
Author Peter Drucker also tries to confront the paradox of employee motivation in a world without lifetime employment. ${ }^{61}$ He recommends that employees market themselves for their knowledge and their human capital. They should plan to work in networks, working for corporations, but not as employees of the corporations. He says top management needs to stop emphasizing loyalty, and instead learn how to instill trust. ${ }^{62}$

Janice Klein, a former G.E. Executive turned M.I.T. Sloan Business School Professor, also attempts to provide an answer. ${ }^{63}$ The task, she states, is for managers to "find other means to convince employees that they are in the same boat together." to equality of sacrifice in times of workforce reductions. ${ }^{65}$ Klein also urges that jobs be designed to provide an avenue for educating employees. ${ }^{66}$

Clearly, one of the most important elements in the new employment relationship is the promise of training that will enable employees to develop their human capital. Employers promise employability that they will enable employees to develop their human capital. Rosabeth Moss Kanter observes that "[t]he chance to learn new skills or apply them in new arenas is an important motivator in a turbulent environment because [it is] oriented toward securing the future. ${ }^{167}$ Towers Perrin, a leading human resource consulting firm, counsels employers: "To attract the right people, organizations are adopting total reward strategies that include learning and development opportunities and the creation of better work environments, in addition to the traditional pay and benefits."

Another feature of the new employment relationship involves the promise of opportunities to network. Not only can employees raise their

nars-the equivalent of a month a year.

-Provide challenging jobs and rotating assignments that allow growth in skill even without promotion to "higher" jobs. ...

-Retrain employees as soon as jobs become obsolete....

-Provide three-month educational sabbaticals or external intemships every five years.

-Find job opportunities in our network of suppliers, customers, and venture part-

Id. ners.

${ }^{61}$ See DRUCKER, supra note 16, at 71-72.

${ }^{62}$ See id at 71.

${ }^{63}$ See Janice Klein, The Paradox of Quality Management: Commitment, Ownership, and Control, in THE POST-BUREAUCRATIC ORGANIZATION 178, 284-85 (Charles Hecksher \& Anne Donnellon, eds., 1994).

${ }^{64}$ Id. at 191.

${ }^{65}$ Id.

${ }^{66}$ Id. at 191-92.

${ }^{67}$ KANTER, supra note 16 , at 53.

${ }^{68}$ Global Survey Highlights Growth in Variable Pay, TOWERS PERRIN MONITOR (Nov. 1999), at http://www.towers.com/towers/publications/publications_frame.asp?target-pubs_date.htm (on file with the Connecticut Law Review). 
human capital, they can enhance their "social capital" by meeting and interacting with others from other departments within the firm, with customers and suppliers of the firm, and even with competitors. By redefining jobs in competency terms, each employee is a professional in his or her particular area. They are sent to trade conferences of other similar professionals to network and keep up to date.

The new employment relationship also involves compensation systems that peg salaries and wages to market rates rather than internal institutional factors. The emphasis is on differential pay to reflect differential talents and contributions. ${ }^{69}$ Thus, for example, Towers Perrin urges its clients to "reward[] results, not tenure, even at the hourly level."" It also advocates a "[s]ignificantly disproportionate share of all pay programs for highperforming employees," and "differen[t] deals based on employee contribution." faction amongst lower-performing employees, and says:

Top Companies also plan for and achieve higher turnover rates. This strategy is based on the hypothesis that significant pay differentiation provides more motivation for the average and poor contributors to leave as they can get a better deal at other companies which tend to offer higher levels of base pay. ${ }^{72}$

Other features of the new employment relationship are a flattening of hierarchy, prospects for lateral as well as vertical movement within and among organizations, and contact with firm constituents, including suppliers and customers. It also involves the use of company-specific dispute resolution devices to redress perceived instances of unfairness. ${ }^{73}$

We can thus make a chart comparing the new to the old employment relationship:

${ }^{69}$ See, e.g., KANTER, supra note 16 , at 175 (reporting that "the tide is moving . . . toward more varied individual compensation based on people's own efforts").

${ }^{70}$ Pay Attention! How to Reward Your Top Employees; Sleep Well Last Night?, PERSP. ON TOTAL REWARDS (Jan. 2000), at http://www.towers.com/publications/publications_frame.asp?target-pubs _date.htm (on file with the Connecticut Law Review).

${ }^{71}$ Id.

72 Id.

${ }^{73}$ See Alexander J.S. Colvin, The Relationship Between Employment Arbitration and Workplace Dispute Resolution Procedures, 16 OHIO ST. J. DiSP. RESOL. 643 (2001) (discussing the development of peer review, open door policies, management appeal boards, mediation, and arbitration at TRW in the 1990s); Katherine Stone, Dispute Resolution in the Boundaryless Workplace, 16 OHIO J. DiSP. RESOL. 467 (2001); Susan Sturm, Second Generation Employment Discrimination: A Structural Approach, 101 COLUM. L: REV. 458, 489-521 (2001) (describing innovative dispute resolution programs in three corporations that attempt to address problems involving sexual harassment). 
Figare 1.

Old Employment Relationship

job security

firm specific training

deskilling

promotion opportunities

command supervision

longevity linked pay \& benefits

collective bargaining and grievance

procedures

\author{
New Employment Relationship \\ employability security \\ general training \\ upskilling \\ networking opportumities \\ micro-level job control \\ market-based pay \\ dispute-resolution procedures individual
}

\section{THE EVOLVING LAW OF POST-EMPLOYMENT RESTRAINTS}

Due to the importance of employee knowledge in today's business world, a growing number of disputes have arisen when employees leave their jobs and try to take their knowledge with them. Firms value not merely specific technical knowledge, such as computer code or biotechnical discoveries, but also more mundane types of knowledge, such as how the business operates, how the goods are produced, how paperwork flows, and how files are organized. ${ }^{74}$ Employees also have valuable knowledge about the firm's product and the environment in which the firm competes, including knowledge of business plans, upcoming projects, past projects, and past experiences. There is also enormous value in employees' knowledge about customers, markets, and competitors. One particularly valuable type of knowledge is called a "negative trade secret."75 A "negative trade secret" is the knowledge of products tested or systems tried that have proven to be unproductive. ${ }^{76}$ Such knowledge in the hands of a competitor can save large expenditures on duplicative and wasteful efforts in pursuit of dead ends. ${ }^{77}$

${ }^{74}$ See STEWART, supra note 2, at 71-78 (describing the importance of tacit knowledge and other informal forms of intellectual capital to organizations).

${ }^{75}$ See Nathan Hamler, The Impending Merger of the Inevitable Disclosure Doctrine and Negative Trade Secret: Is Trade Secret Law Headed in the Right Direction?, 25 J. CORP. L. 383, 384 (2000) (defining "negative trade secret").

${ }^{76} I d$.

${ }^{77}$ On the role of intellectual capital in organizations, see generally Bruce A. Lehman, Intellectual Property: America's Competitive Advantage in the Twenty-First Century, 31 COLUM. J. WORLD BUS. 6, 10 (1996); STEWART, supra note 2, at $71-78$ (describing the importance of tacit knowledge and other informal forms of intellectual capital to organizations). On negative knowledge, see Hamler, supra note 75; Thomas J. Methvin, Business Torts from a Plaintiff's Perspective, 60 ALA. LAW. 415, 415 
Employers use a variety of legal theories to restrain former employees from using knowledge obtained at their firms. Some of these theories include: misappropriation of trade secrets, breach of a duty of loyalty, industrial espionage, and when applicable, breach of nondisclosure agreements and covenants not to compete. The various legal doctrines offer different types of protection for valuable information. Trade secret protection prevents an employee from disclosing knowledge that qualifies as a "trade secret"-a vague and uncertain standard at best. ${ }^{78}$ Breach of duty of loyalty and industrial espionage claims involve allegations that an employee used knowledge gained from one employer on behalf of a competing enterprise. $^{79}$ Covenants not to compete have the potential to prevent an employee from using any of her knowledge for the benefit of a competitor. ${ }^{80}$ Similarly, a covenant not to disclose confidential information protects only the particular information that is the subject of the agreement. ${ }^{81}$ Despite their differences, all of these doctrines implicate the underlying question: Who "owns" the employee's human capital?

Current judicial approaches to the issue of ownership of human capital often favor the employer. ${ }^{82}$ However, as will be seen below, these approaches are out of step with the new employment relationship, in which skills, training, networking, and horizontal flexibility are important terms of the employment contract. This Section analyzes the issue of ownership of human capital in light of the tacit understandings of the new employment relationship. The analysis presented here suggests that courts should carefully scrutinize any efforts by employers to place restrictions on the portability of the employee's human capital in order to assure that the employer has not breached the explicit and implicit terms of the employment contract.

\section{A. Covenants Not to Compete}

Covenants not to compete and covenants not to disclose information have become commonplace in employment contracts over the past ten years. In addition to their increased presence in negotiated, fixed term em-

(1999). See also Brunswick Corp. v. Jones, 784 F.2d 271, 275 (7th Cir. 1986) (noting the irreparable harm that can be caused by breaches of duty of loyalty).

${ }^{78}$ See generally SECTION OF LABOR \& EMPLOYMENT LAW, AM. BAR ASS'N, TRADE SECRETS: A STATE-BY-STATE SURVEY (Amold H. Pedowitz et al. eds., 1997) [hereinafter TrADE SECRETS].

${ }^{79}$ See generally SECTION OF LABOR \& EMPLOYMENT LAW, AM. BAR ASS'N, EMPLOYEE DUTY OF LOYALTY: A STATE-BY-STATE SURVEY (Brian M. Malsberger et al. eds., 2d ed. 1998) [hereinafter EMPLOYEE DUTY OF LOYALTY].

${ }^{80}$ See generally SECTION OF LABOR \& EMPLOYMENT LAW, AM. BAR ASS'N, COVENANTS NOT TO COMPETE: A STATE-BY-STATE SURVEY (Brian M. Malsberger et al. eds., 2d ed. 1996) [hereinafter COVENANTS NOT TO COMPETE].

\footnotetext{
${ }^{81}$ See generally id.

${ }^{82}$ See infra text accompanying notes 97-100.
} 
ployment contracts, such covenants have also been inserted into at-will employment relationships. There has also been a corresponding increase in litigation over them. ${ }^{83}$ A search on the legal database, Westlaw, for cases involving covenants not to compete and trade secrets revealed the number of reported cases to be as follows: ${ }^{84}$

Figare 2.

$\frac{1970-}{1974} \quad \frac{1975-}{1979} \quad \frac{1980-}{1984} \quad \frac{1985-}{1989} \quad \underline{1990-} \quad \underline{1994} \quad \underline{1995-}$

All states file:

covenants not to compete

noncompete covenants

trade secrets

$\begin{array}{cc}127 & 235 \\ 40 & 68 \\ 156 & 233\end{array}$

235

233
314

123

367
47

178

510
512

171

312
509

193

719

All federal file:

covenants not to compete

noncompete covenants

trade secrets

125
29
258

135
33
328

185

45

546

264
66
779

340

99 1011
368

161 1256

Admittedly, this data does not represent a scientific survey. Westlaw may not contain all of the decisions relevant to this topic, the search terms used likely do not capture all of the cases, and there is possibly some double counting due to overlap in the cases. However, the data does reveal an unequivocal trend that is consistent with observations by scholars and practitioners. $^{85}$

At the same time that cases have proliferated, courts have become increasingly receptive to employer efforts to limit employee use of human capital. As will be shown below, courts have adopted expansive definitions of trade secrets and employees' duty of loyalty, and have expanded the circumstances under which they will enforce covenants not to compete.

\section{Restrictive Covenants and At-Will Employees}

Covenants not to compete occupy a peculiar legal "Never-Never Land"

${ }^{83}$ See Lowry, supra note 10, at 519 (commenting on the dramatic increase in trade secret litigation); Staidl, supra note 10, at 96 (same).

84 COVENANTS NOT TO COMPETE, supra note 80; EMPLOYEE DUTY OF LOYALTY, supra note 79; TRADE SECRETS, supra note 78.

${ }^{85}$ See sources cited supra note 10. 
between contract and tort, in which party consent and externally imposed obligation are intimately and complexly intertwined. When an employment relationship includes a covenant not to compete or not to disclose specific information, it is reasonable to assume that the employee has consented to restrictions on his or her post-employment activities. Accordingly, there is a strong argument for courts to enforce the covenant, perhaps with some scrutiny to ensure that the agreement was the product of actual consent and that the terms were disclosed. A consent-based approach to noncompete and nondisclosure covenants might, for example, permit courts to ensure that a covenant was not buried in fine print in an employment handbook or otherwise hidden from view. It might also be legitimate for a court to require an employer to identify the confidential information that is subject to a nondisclosure agreement with particularity at the outset, so that employers cannot use such agreements to impose far-reaching restrictions on employees at the point of termination. A consent-based approach would impose no further scrutiny in determining whether a noncompete and nondisclosure covenant is enforceable. ${ }^{86}$

However, with covenants not to compete, the existence of consent is only the beginning of a court's analysis. Historically, courts were suspicious of noncompete covenants in the employment setting because they believed they were often the result of vastly unequal bargaining power and thus contracts of adhesion. ${ }^{87}$ While the existence of one-sided or oppressive terms in an employment contract is not usually treated as a ground to vacate the contract, noncompete promises have historically been scrutinized with a jaundiced eye. One reason for this special treatment was that noncompete clauses implicate the right of an individual to earn a living. For example, in one case of obvious overreaching by an employer, a court invalidated a covenant that restricted a janitorial employee from working as a janitor for ten years. ${ }^{88}$ Courts are also suspicious of noncompete clauses because they impose costs on society as a whole by suppressing employee mobility, interfering with the labor market, and restraining trade. ${ }^{89}$

${ }^{86}$ A strict consent-based approach is advocated by Richard Posner in his dissenting opinion in Outsource International, Inc. v. Barton, 192 F.3d 662, 669-75 (7th Cir. 1999). Posner said, "I can see no reason in today's America for judicial hostility to covenants not to compete. It is possible to imagine situations in which the device might be abused ... but the doctrines of fraud, duress, and unconscionability are available to deal with such situations." Id. at 670 (Posner, J., dissenting) (citations omitted).

${ }^{87}$ They are more lenient in their enforcement of nondisclosure agreements for reasons discussed infra Part IV.B.

${ }^{88}$ See Frederick v. Prof'l Bldg. Maint. Indus., Inc., 344 N.E.2d 299, 302 (Ind. Ct. App. 1976).

${ }^{89}$ See, e.g., Insulation Corp. of Am. v. Brobston, 667 A.2d 729, 733 (Pa. Super. Ct. 1995); see also Holloway v. Faw, Casson \& Co., 552 A.2d 1311, 1326 (Md. Ct. Spec. App. 1989) (stating that "Maryland, like other jurisdictions, has never considered noncompetition clauses according to strict traditional contract theories ..."). See generally Closius \& Schaffer, supra note 9 (suggesting the need to limit the post-associational restraint of former employees because of the harmful effects such cove- 
As a result of these concerns, courts historically have not enforced noncompete covenants as a matter of course, but rather have held that post termination employment covenants were presumptively void..$^{90}$ Over time, most state courts have become more receptive to enforcing covenants not to compete and have adopted a "rule of reason" approach. ${ }^{91}$ The rule of reason approach says that an employment covenant not to compete must be reasonable to be enforceable. In order for a covenant to be reasonable, it must be only as broad as is necessary to protect a legitimate interest of the employer, and must be reasonable in duration and geographic scope. ${ }^{92}$ In addition to these factors, courts traditionally required that the covenant not unduly burden the employee or unduly harm the public. ${ }^{93}$

What a court considers to be reasonable duration and geographic scope varies from state to state and from case to case. Some courts have upheld extremely broad covenants while some have struck down very narrow ones. $^{94}$ Recently, some courts have upheld covenants that are wider in geographic scope than those they would have affirmed in the past on the grounds that the firm seeking to enforce the covenant competes in a nationwide or worldwide market. ${ }^{95}$ However, some courts have restricted the time of an allowable covenant on the grounds that in today's fast-moving

nants can cause).

${ }^{90}$ See, e.g., Purchasing Assocs., Inc. v. Weitz, 196 N.E.2d 245, 248 (N.Y. 1963); Arthur Murray Dance Studios of Cleveland, Inc. v. Witter, 105 N.E.2d 685, 693 (Ohio C. C.P. 1952).

${ }^{91}$ See Ronald J. Gilson, The Legal Infrastructure of High Technology Industrial Districts: Silicon Valley, Route 128, and Covenants Not to Compete, 74 N.Y.U. L. REv. 575, 603-04 (1999) (describing the origin of the rule of reason approach). A few states, including California, still refuse to enforce covenants not to compete. See Bayer Corp. v. Roche Molecular Sys., Inc., 72 F. Supp. 2d 1111, 1112 (N.D. Cal. 1999).

92 See RESTATEMENT (SECOND) OF CONTRACTS § 188(1)(a) (1981) (stating that a covenant not to compete is only enforceable if "the restraint is [no] greater than is needed to protect the promisee's legitimate interest") (emphasis added); see also Edward T. Ellis et al., Protection for an Employer's Investment in Its Key Employees: Recent Caselaw on Covenants Not to Compete and Trade Secrets, in 3 CuRrent Developments in EMPLOYMENT LAW, ALI-ABA COURSE OF Study 1321, 1324-25 (1998) (discussing the "reasonableness requirement" which a covenant not to compete must satisfy in order for it to be upheld by the courts).

93 See RESTATEMENT (SECOND) OF CONTRACTS § 188(1)(a) \& (b) (1981); see also Ellis et al., supra note 92 , at 1324.

94 Compare Shipley Co., Inc. v. Clark, 728 F. Supp. 818, 828 (D. Mass. 1990) (upholding a oneyear covenant for salesman's dealings with former customers), and Loranger Constr. Co. v. C. Franklin Corp., 247 N.E.2d 391, 393 (Mass. 1969) (upholding a three-year restriction on a natural gas service employee), and Superior Gearbox Corp. v. Edwards, 869 S.W.2d 239, 248 (Mo. Ct. App. 1993) (upholding a five-year restriction of a gearbox manufacturer employee), and Karlin v. Weinberg, 372 A.2d 616,619 (N.J. Super. Ct. App. Div. 1977) (stating that a five-year restriction on a doctor was reasonable), affd, 390 A.2d 1161 (N.J. 1978), with Blalock v. Perfect Subscription Co., 458 F. Supp. 123, 127-28 (S.D. Ala. 1978) (finding a 120-day covenant against a magazine salesman unreasonable), aff'd 599 F.2d 743 (5th Cir. Ala. 1979); and Birmingham Television Corp. v. DeRamus, 502 So. 2d 761, 764 (Ala. Civ. App. 1986) (finding a six-month restriction of an at-will employee unreasonable).

${ }^{95}$ See, e.g., Ackerman v. Kimball Int'l, Inc., 652 N.E.2d 507, 510 (Ind. 1995) (upholding a worldwide covenant not to compete). 
and competitive environment, an employee's knowledge loses its value quickly. ${ }^{96}$

Restrictive covenants involving at-will employees are particularly problematic and sometimes receive additional scrutiny. An at-will employee is one who can be fired for a good reason, a bad reason, or no reason at all. ${ }^{97}$ If an at-will employee is fired without cause, she has no redress for her unjust dismissal; yet, if there is a covenant in effect, she can be prevented from performing another job. Because courts usually enforce noncompete covenants with injunctions, an at-will employee who has been fired unfairly can be barred from accepting all subsequent employment in the type of work that she is best able to perform. That is, an employee subject to a restrictive covenant, who is fired unfairly, is left without a job and is unable to take another one in her specific area of expertise. ${ }^{98}$

To avoid these harsh consequences, some courts have imposed stricter requirements for enforcing noncompete covenants against at-will employees than they do against employees on fixed term contracts. One way that some courts do so is to require that to be enforceable, a covenant must be "ancillary to an otherwise valid transaction," i.e., part of a real exchange or supported by valid consideration." The "ancillary to an otherwise valid transition" requirement is intended to ensure the presence of a real bargain

${ }^{96}$ See, e.g., EarthWeb, Inc. v. Schlack, 71 F. Supp. 2d 299, 313 (S.D.N.Y. 1999) (holding that a year long covenant not to compete was unreasonably long due to the "dynamic nature of the industry, its lack of geographical borders," and the fact that the employees' knowledge would lose its value quickly if he did not keep abreast of constant changes).

97 Payne v. Western \& Atlantic RR, 81 Tenn. 507 (1884). See also Adair v. United States, 208 U.S. 161 (1908).

${ }^{98}$ See, e.g., Lofton v. TLC Laser Eye Centers, Inc., No. CCB-00-1667, 2001 U.S. Dist. LEXIS 1476 , at $* 16-* 17$ (D. Md. Feb. 8, 2001) (finding that whether termination is in good faith or not is not material to enforcement of restrictive covenant); Hogan v. Bergen Brunswig Corp., 378 A.2d 1164 (N.J. Super. Ct. App. Div. 1977) (reversing lower court and upholding covenant against employee who was fired, without regard to whether termination was for good cause). In Wright \& Seaton, Inc. $v$. Prescott, 420 So. 2d 623, 628 (Fla. Dist. Ct. App. 1982), the court opined:

Let us assume in the present case that immediately after appellee appended his name to the parties' employment agreement, appellant delivered to him then and there a written notice that his employment was forthwith terminated without cause; or that this same notice was delivered to him one day, one week, or one month after employment had continued pursuant to the agreement, in which period no trade secrets became known to appellee. Would appellee be bound by his covenant or was the "promise" of continued employment only illusory? Accordingly, we are troubled by the phrase "terminable at will" that is employed in the three opinions in the absence of supportive analysis. Nevertheless, they represent the goverming law in Florida on which employers and employees have relied for over twenty years and appellee has not provided us with argument sufficientiy persuasive to disregard them.

Id.

${ }^{99}$ See, e.g., Loewen Group Int'l, Inc. v. Haberichter, 912 F. Supp. 388, 392 (N.D. Ill. 1996), aff'd in part and rev'd in part on other grounds, No. 97-3825 \& 97-3877, 1998 U.S. App. LEXIS 28514, at * 1 (7th Cir. Nov. 9, 1998); see also RESTATEMENT (SECOND) OF CONTRACTS § 188(1) (declaring when a promise that imposes restraints that are ancillary to a valid transaction or relationship is unreasonable and when it is allowed). 
and to prevent an employer, particularly in an at-will employment context, from getting something for nothing. ${ }^{100}$

Recently, many courts have either abandoned or modified the "ancillary to a valid transaction" requirement in order to permit enforcement of noncompete covenants against at-will employees. ${ }^{101}$ The courts do so by defining an initial offer of employment, even if it is at-will employment, as valid consideration for the covenant. ${ }^{102}$ For a time, some courts refused to enforce a noncompete covenant that was presented to an at-will employee after employment had commenced, on the grounds that consideration was lacking. However, most courts now believe that the post-employment situation should not be treated differently from the initial hiring. ${ }^{103}$ Thus, for example, an Ohio appellate court recently noted that "[a]s a practical matter every day is a new day for both employer and employee in an atwill relationship. [Thus] we see no substantive difference between the promise of employment upon initial hire and the promise of continued employment subsequent to "day one." "'104

The recent trend of relaxing the "ancillary to a valid transaction":requirement revives the concern that enforcing covenants against at-will employees can yield harsh and unfair results. To avoid such a harsh result, some courts have taken to protecting at-will employees by refusing to en-

${ }^{100}$ See, e.g., Loewen Group Int'l, Inc., 912 F. Supp. at 392 (discussing the need to ensure that restrictive covenants are "connected to legitimate business interests"); Applied Micro, Inc. v. SJI Fulfillment, Inc., 941 F. Supp. 750, 753 (N.D. Ill. 1996) (describing the test for determining the enforceability of a restrictive covenant); Creative Entm't, Inc. v. Lorenz, 638 N.E.2d 217, 219 (Ill. App. Ct. 1994) (stating that covenants which restrain trade must be reasonable and in accordance with public policy); Insulation Corp. of Am. v. Brobston, 667 A.2d 729, 733 (Pa. Super. Ct. 1995) (arguing that a noncompetition covenant which caused "undue oppression" on a former employee's ability to eam a living was unreasonable); RESTATEMENT (SECOND) OF CONTRACTS $§ 188(1)$ (stating that if "the restraint is greater than is needed to protect the promisee's legitimate interest, or the promisee's need is outweighed by the haroship to the promisor and the likely injury to the public" than it is unreasonably in restraint of trade); see also Staidl, supra note 10, at 97-98 (discussing the court's desire to ensure that employers do not force their employees to sign noncompetition covenants).

${ }^{101}$ See, e.g., Woodfield Group, Inc. v. DeLisle, 693 N.E.2d 464, 466 (IIl. App. Ct. 1998) (finding a restrictive covenant agreement unenforceable for lack of ancillarity); Abel v. Fox, 654 N.E.2d 591, 597 (Ill. App. Ct. 1995) (finding a covenant in an at-will contract enforceable); Fin. Dimensions, Inc. v. Zifer, Nos. C-980960 \& C-980993, 1999 Ohio App. LEXIS 5879, at *10 (Ohio Ct. App. Dec. 10, 1999) (finding that a continuation of parties' relationship was sufficient consideration to support a claim of breach covenant not to compete); see also Uli Widmaier, Covenants Not to Compete, in ANTITRUST AND UNFAIR COMPETITION (IIl. Inst. for Continuing Educ., 1998) (stating that the Creative Entertainment decision has been "roundly criticized" in Illinois).

- ${ }_{102}$ See Staidl, supra note 10, at 102.

103 See Fin. Dimensions, Inc., 1999 Ohio App. LEXIS 5879, at *10 (stating that since 1985, "the majority of courts have rejected" the distinction between covenants presented at the time of commencing at-will employment and those presented after employment has begun, and "hold[ing] that the employer's continued employment of the employee after the employee signs or agrees to the restrictive covenant is sufficient consideration to support the employer's later enforcement of the agreement").

${ }^{104}$ Id. at *11 (quoting Copeco, Inc. v. Caley, 632 N.E.2d 1299, 1301 (Ohio Ct. App. 1992)). 
force a covenant against an at-will employee if the dismissal was unfair. ${ }^{105}$ These courts inquire into the circumstances of the dismissal, and only enforce a post-termination covenant when they find that the dismissal was justified. This approach is a major departure from an at-will regime. It has been proposed that if courts enforce restrictive covenants against at-will employees, they should automatically impose a corresponding obligation on the employer not to discharge the employee except for just cause. ${ }^{106}$ To date, this proposal has not been adopted. Indeed, some courts continue to enforce covenants against at-will employees, notwithstanding the circumstances of their dismissal. ${ }^{107}$

As discussed, the expanded enforcement of restrictive covenants in employment contracts has occurred through judicial reinterpretation of the meaning of reasonableness in time and space, as well as through a relaxation of the requirement of consideration in the at-will context. In addition, expanded enforcement has occurred through a change in judicial attitudes toward revision. In the past, courts usually refused to enforce a covenant notito compete if any part of it was invalid. This all-or-nothing approach gave employers an incentive to draft their covenants narrowly. The current approach of a majority of courts is either to rewrite an invalid covenant and enforce it as rewritten or to delete the invalid portions and enforce the remainder. ${ }^{108}$

The conflicting interests involved in the enforcement of noncompete covenants for at-will employees is illustrated by a sharply drawn battle in the late 1980s and early 1990s in Texas. ${ }^{109}$ In the late 1980s, the Texas Supreme Court handed down four decisions in which it refused to enforce restrictive covenants. ${ }^{110}$ In response, in 1989, the Texas legislature enacted

${ }^{105}$ See, e.g., Prop. Tax Representatives v. Chatam, 891 S.W.2d 153, 156-57 (Mo. Ct. App. 1995); Central Monitoring Serv. v. Zakinski, 553 N.W.2d 513, 520-21 (S.D. 1996). See also Cent. Adjustment Bureau v. Ingram, 678 S.W.2d 28, 35 (Tenn. 1984) (explaining that [a]lthough an at-will employee can be discharged for any reason without breach of the contract, a discharge which is arbitrary, capricious or in bad faith clearly has a bearing on whether a court of equity should enforce a noncompetition covenant").

${ }^{106}$ See Staidl, supra note 10 , at 118.

${ }^{107}$ Examples of cases in which a court looks to see whether the at-will employee was fired unfairly include Prop. Tax Representatives, 891 S.W.2d at 156-57, and Central Monitoring Serv., 553 N.W.2d at 520-21 (refusing to enforce covenant because dismissal was not for good cause). Cases in which the court enforced a restrictive covenant, notwithstanding the faimess of a dismissal are $\mathrm{Ol}$ liver/Pilcher Ins., Inc. v. Daniels, 715 P.2d 1222, 1224 (Ariz. Ct. App. 1985), vacated on other grounds by 715 P.2d 1218, 1224 (Ariz. 1986) (enforcing covenant) and Allen v. Rose Park Pharmacy, 237 P.2d 823,829 (Utah 1951).

${ }^{108}$ See Ellis et al., supra note 92, at 1330-32.

${ }^{109}$ See generally Jeffrey W. Tanyon, Covenants Not to Compete in Texas: Shifting Sands from Hill to Light, 3 TEX. INTELL. PROP. L.J. 143 (1995) (recounting in detail the recent history of noncompete clauses in Texas). See also Light v. Centel Cellular Co. of Texas, 883 S.W.2d 642, 643-44 (Tex. 1994) (recounting the history of the Texas noncompete statute).

110 Martin v. Credit Prot. Ass'n, No. C-7339, 1998 Tex. LEXIS 91, at*1 (Tex. 1988) (“dis- 
a law designed to reverse the state court's approach to restrictive covenants and to expand the situations in which such covenants would be enforced. ${ }^{111}$ Senator John Whitmire, who introduced the legislation, complained that the Texas Supreme Court had pursued a policy "'of [putting] free movement of workers above ... the increased investment in business."112 Whitmire argued that the legislation was necessary to encourage investment in the state. ${ }^{113}$ The Texas Business Bar Foundation, one of only two groups to testify on the bill, also argued that the enforcement of noncompete covenants was necessary for business. ${ }^{114}$ They contended that, by protecting confidential information, the covenants encouraged firms to engage in research and development. ${ }^{115}$

The new statute was passed in $1989,{ }^{116}$ but almost immediately the Texas Supreme Court refused to apply it to at-will employees. ${ }^{117}$ The legislature responded to the court's objection in 1993, when it amended the 1989 statute to explicitly state that restrictive covenants involving at-will employees were enforceable. ${ }^{118}$ The amended statute provides that courts should enforce covenants even against at-will employees, so long as they are reasonable with regard to time, geographic area, and scope of activity, and narrowly tailored to protect the good will or other business interest of the promisee. ${ }^{119}$ Notably, the statute states that when a covenant is unreasonably broad in time, space or scope of activity, the court should rewrite

solv[ing] the injunction and holding the restrictive covenant void in all respects"), withdrawn, 793 S.W.2d 667, 670 (Tex. 1990) (holding that the restrictive covenant was unreasonable and therefore "void in all respects"); DeSantis v. Wackenhut Corp., No. C-6617, 1988 Tex. LEXIS 97, *16-*17 (Tex. 1988) (holding that unreasonable covenant was unenforceable because it was not necessary for the protection of the employer and lacked consideration), withdrawn, 793 S.W.2d 670 (Tex. 1990) (finding that non-compete agreement was unreasonable and unenforceable because it was not "necessary to protect any legitimate business interest"); Bergman v. Norris of Houston, 734 S.W.2d 673, 674 (Tex. 1987) (holding that covenants not to compete were unenforceable against employees where there was "no sale of a business or imparting of specialized knowledge or information"); Hill v. Mobile Auto Trim, Inc., 725 S.W.2d 168, 169 (Tex. 1987) (holding that "non-competition agreement [was] a restraint on trade and [was] unreasonable" and therefore "void in all respects").

111 Act of June 16, 1989, ch. 1193, § 1, 1989 Tex. Gen. Laws 4852-53 (codified as amended at TEX. BUS. \& COM. CODE ANN. $\S 15.50$ to 15.52 (Vernon Supp. 2002)).

112 Tanyon, supra note 109, at 188 (quoting Senator John Whitmire).

${ }^{113}$ See id.

114 See id. at 180 (citing Texas Business Law Foundation).

${ }^{115}$ See id. (citing Texas Business Law Foundation).

116 Act of June 16, 1989, ch. 1193, § 1, 1989 Tex. Gen. Laws 4852-53 (codified as amended at TEX. BUS. \& COM. CODE ANN. §§ 15.50 to 15.52 (Vernon Supp. 2002)).

117 DeSantis v. Wackenhut Corp., 793 S.W.2d 670, 685 (Tex. 1990); Martin v. Credit Prot. Ass'n, Inc., 793 S.W.2d 667, $669-670$ (Tex. 1990); see Tanyon, supra note 109, at 147 (discussing DeSantis and Martin, and noting that the court in these cases refused to apply statute to at-will employees).

${ }^{118}$ See Tanyon, supra note 109, at 147-48; see also Act of June 19, 1993, ch. 965, § 1, 1993 Tex. Gen. Laws 4201-02 (codified at TEx. BUS. \& COM. CODE ANN. $\S \S 15.50$ to 15.52 (Vernon Supp. 2002)).

${ }^{119}$ See TEX. Bus. \& Сом. COdE ANN. $\$ 15.51$ (Vemon Supp. 2002). 
the covenant to render it enforceable. ${ }^{120}$

Even after the 1993 amendment, the Texas Supreme Court was reluctant to enforce restrictive covenants against at-will employees. The first case under the new statute, Light v. Centel Cellular Co., ${ }^{121}$ involved a salesperson who had agreed to a noncompete agreement after working for the company as an at-will employee for two years. ${ }^{122}$ After the company changed hands, the salesperson quit and the company attempted to enforce the covenant. ${ }^{123}$ When the case first came before the Texas Supreme Court under the 1989 statute, the Court refused to enforce the covenant on the grounds that the employee was at-will. ${ }^{124}$ The opinion was later withdrawn in light of the 1993 statute, and the case was reheard. ${ }^{125}$ In 1994, the court applied the 1993 statute, but gave it a razor-thin interpretation. ${ }^{126}$ The court held that because Light's at-will employment agreement contained several terms, the covenant was ancillary to an enforceable agreement. ${ }^{127}$ However, the court also concluded that the covenant not to compete was not ancillary to the enforceable aspects of the agreement, and so it did not enforce the noncompete covenant. ${ }^{128}$

\section{Legitimate Employer Interests and the New Employment Relation- ship}

Another area in which judicial enforcement of noncompete covenants has changed is the conception of what constitutes a legitimate protectable employer interest. A court will not enforce a covenant if it is solely a means to restrain trade. Rather, the long-standing view has been that to be enforceable, a covenant not to compete must protect an employer's interest in a trade secret or in other "confidential information." 129

${ }^{120}$ Id. § 15.51. The statute states:

If the covenant is found to be ancillary to ... an otherwise enforceable agreement but contains limitations as to time, geographical area, or scope of activity to be restrained that are not reasonable and impose a greater restraint than is necessary to protect the goodwill or other business interest of the promisee, the court shall reform the covenant to the extent necessary to cause the limitations contained in the covenant ... to impose a restraint that is not greater than necessary to protect the goodwill or other business interest of the promisee and enforce the covenant as reformed.

Id. (emphasis added).

${ }_{121} 883$ S.W.2d 642 (Tex. 1994).

122 Id. at 643.

123 Id.

${ }^{124}$ Id.

${ }^{125}$ Id. at 643 n.l.

${ }^{126}$ Id. at 643-47.

${ }^{127}$ Id. at 645-46.

${ }^{128}$ Id. at 647.

${ }^{129}$ See Edmund W. Kitch, The Expansion of Trade Secrecy Protection and the Mobility of Management Employees: A New Problem for the Law, 47 S.C. L. REV. 659, 667 (1996); Lowry, supra note 10 , at 524-25. 
The historical link between noncompete covenants and trade secrets is somewhat paradoxical because disclosure of trade secrets and confidential information can be restrained in the absence of a covenant. ${ }^{130}$ However, it has been argued that, for procedural reasons, it is difficult to obtain enforcement of a trade secret, so that a restrictive covenant provides employers with important additional protection. ${ }^{131}$ At the same time, some scholars have posited that courts are more likely to enjoin misappropriation of a trade secret or confidential information in the face of a covenant not to compete because the existence of a covenant permits the court to avoid the difficult legal issue of determining what constitutes a trade secret. ${ }^{132}$ An illustrative case is Comprehensive Technologies International, Inc. v. Software Artisans, Inc., ${ }^{133}$ in which the Fourth Circuit enforced a very broad covenant-one that would prevent a former executive employee from working in any capacity for a competitor, even as a janitor or file clerk. ${ }^{134}$ The court justified its decision on the grounds that the employee had access to confidential information concerning both the products and customers of the former employer, and that "[i]t will often be difficult ... to prove that a competing employee has misappropriated trade secret information belonging to his former employer." 135 This rationale suggests that the court was acting to protect a trade secret, not to enforce the parties' agreement, but that the presence of a covenant enabled the court to sidestep the difficult trade secret issue. In such cases, courts enforce restrictive covenants in order to protect trade secrets, not to effectuate party consent. ${ }^{136}$

Courts have recently expanded the types of employer interests that they consider legitimate subjects of noncompete covenants beyond the narrow trade secret rationale. Many courts no longer require that there be a trade secret involved at all. ${ }^{137}$ For example, courts have enforced covenants

${ }^{130}$ See Kitch, supra note 129, at 667 (noting there is "circular[ity] when the scope of trade secrecy is defined by the scope of the confidentiality obligation, and the permissible scope of the confidentiality obligation is defined by the scope of trade secrecy protection"); see also Closius \& Schaffer, supra note 9, at 547-48 (arguing that because the only circumstance in which courts should enforce a covenant is when there is a trade secret or confidential information, the existence of a noncompete covenant is superfluous).

${ }^{131}$ See Gilson, supra note 91, at 605-06.

${ }^{132}$ Closius \& Schaffer, supra note 9, at 551.

${ }^{133} 3$ F.3d 730 (4th Cir. 1993), vacated and case dismissed pursuant to settlement, No. 92-1837, 1993 U.S. App. LEXIS 28601, at *1 (4th Cir. Sept. 30, 1993).

${ }^{134}$ Id. at 738.

${ }^{135}$ Id. at 739 .

${ }^{136}$ See, e.g., Water Servs., Inc. v. Tesco Chems., Inc., 410 F.2d 163, 170-71 (5th Cir. 1969) ("[S]ince it may be difficult to determine, as a matter of law, what is a trade secret, the covenant not to compete is a pragmatic solution to the problem of protecting confidential information.").

${ }^{137}$ See, e.g., Fin. Dimensions, Inc. v. Zifer, Nos. C-980960 \& C-980993, 1999 Ohio App. LEXIS 5879, at*14-*28 (Ohio Ct. App. Dec. 10, 1999). 
when a manicurist left to work for another nail salon, ${ }^{138}$ a carpet salesman took a job with another carpet retailer, ${ }^{139}$ and a liquor deliveryman went to work for another distributor. ${ }^{140}$ In doing so, the courts have expanded the set of interests they consider legitimate to protect with a noncompete covenant. Two factors cited with increasing frequency as being legitimate employer interests are: (1) contact with customers, and (2) employer provision of training. ${ }^{141}$ Courts use the presence of either of these factors as evidence from which to infer that a covenant has a legitimate, rather than an anticompetitive, purpose. ${ }^{142}$ However, as discussed below, each of these factors is in tension with the terms of the new employment relationship.

\section{a. Customer Contact}

Firms operating in competitive markets greatly value their relationships with customers, viewing customer relationships as important assets of the firm. ${ }^{143}$ Yet they are vulnerable assets because departing employees who have dealt with a firm's customers have the ability to steal them away. Companies often use noncompete covenants to try to protect customer information from falling into the hands of competitors through the agency of a departing employee. ${ }^{144}$ As a result, customer information is the most commonly litigated trade secret issue. ${ }^{145}$

With increasing frequency, courts rule that customer contact provides a basis for enforcing a covenant not to compete. ${ }^{146}$ Some courts treat customer lists as trade secrets, but some do not. ${ }^{147}$ Some courts find that a

${ }^{138}$ Nail Boutique, Inc. v. Church, 758 S.W.2d 206, 210-11 (Mo. Ct. App. 1988).

139 Reardigan v. Shaw Indus., Inc., 518 S.E.2d 144, 148 (Ga. Ct. App. 1999).

${ }^{140}$ E. Distrib. Co., Inc. v. Flynn, 567 P.2d 1371 (Kan. 1977).

141 See infra Parts II.A \& B, III.

142 See Closius \& Schaffer, supra note 9, at 547-48. See, e.g., Aero Kool Corp. v. Oosthuizen, 736 So. 2d 25, 26 (Fla. Dist. Ct. App. 1999) (finding employment agreement and six month covenant not to compete furthered legitimate business interest); see also Freund v. E.D. \& F. Man Int'l, Inc., 199 F.3d 382, 385 (7th Cir. 1999) (suggesting that under Illinois law, an employer's investment in its employees' training is grounds to enforce a covenant not to compete).

143 See Henry J. Silberberg \& Eric G. Lardiere, Eroding Protection of Customer Lists and Customer Information Under the Uniform Trade Secrets Act, 42 BUS. LAw. 487, 487 (1987).

${ }^{144}$ See id.

145 See id.

${ }^{146}$ See Whitmore, supra note 9, at 494 n.67, 503-06 (surveying 105 cases involving noncompete covenants from 1966 through 1988 from twenty-seven states showing that an employee's relationship with customers is a very important factor given by courts as a reason for enforcing or not enforcing covenants).

147 For cases that treat customer lists as a trade secret, see N. Atl. Instruments, Inc. v. Haber, 188 F.3d 38, 44 (2d Cir. 1999) (holding that an employer's list of individual client contacts is a protectable trade secret, provided it is "not otherwise readily ascertainable"), Suncoast Tours, Inc. v. Lambert Group. Inc., No. 98-5627, 1999 U.S. Dist. LEXIS 17635, at *21-*25 (D.N.J. Nov. 10, 1999) (finding that under certain circumstances-such as when it is a product of unique skill or creativity-a list of customers may constitute a trade secret), Merrill Lynch, Pierce, Fenner \& Smith. Inc. v. Ran, 67 F. 
customer list is a trade secret when it was compiled from information that was difficult to obtain and had been kept strictly confidential. ${ }^{148}$ Conversely, if the information is publicly available, courts generally do not give it trade secret protection. ${ }^{149}$ When a customer list is a trade secret, enforcing a restrictive covenant to prevent the use of a customer list would fall within the trade-secret-as-legitimate-interest rationale for enforcement of covenants. However, even courts that do not consider a customer list to be a trade secret will usually enforce a covenant against an employee who has knowledge of a customer list or customers' preferences, and is likely to use the knowledge on a new job. ${ }^{150}$ Thus, while trade secret law alone does not always protect customer lists, noncompete covenants almost always

Supp. 2d 764, 775 (E.D. Mich. 1999) (noting that federal courts have held Merrill Lynch's customer list to trade secret status), Nobel Biocare USA, Inc. v. Lynch, No. 99 C 5774, 1999 WL 958501, at *3 (N.D. III. Sept. 15, 1999) (finding that the list of the narrow group of plaintiff's top twenty customers in the Illinois territory constitutes a trade secret), and Wright v. Power Indus. Consultants, Inc., 508 S.E.2d 191, 196 (Ga. Ct. App. 1998) (holding that where a business makes a reasonable effort to maintain the secrecy of its customer lists, a court may grant an interlocutory injunction under the Trade Secrets Act), overruled in part by Advance Tech. Consultants, Inc. v. Roadtrac, LLC., 55I S.E.2d 735 (Ga. Ct. App. 2001). But see Lowry, supra note 10, at 522-23 (noting that states vary as to whether or not they treat customer lists as a trade secret).

${ }^{148}$ See, e.g., Alagold Corp. v. Freeman, 20 F. Supp. 2d 1305, 1315-16 (M.D. Ala. 1998) (finding that the plaintiff did not satisfy the requirement to undertake reasonable efforts to maintain the secrecy of its information); AmeriGas Propane, L.P. v. T-Bo Propane, Inc., 972 F. Supp. 685, 698-700 (S.D. Ga. 1997) (finding that because the information in question was not "irrefutably publicly ascertainable" by proper means, the plaintiff satisfied this requirement determining a trade secret); Ability Search, Inc., v. Lawson, 556 F. Supp. 9, 15 (S.D.N.Y. 1981) (holding that information not readily ascertainable by defendants is entitled to trade secret protection).

${ }^{149}$ See, e.g., Trans-Clean Corp. v. Terrell, No. CV 970348039S, 1998 Conn. Super. LEXIS 717, at *22-*23 (Conn. Super. Ct. Mar. 17, 1998) (refusing to recognize a trade secret where the plaintiff failed to show a company policy with regard to maintaining the secrecy of customer contacts); Templeton v. Creative Loafing Tampa, Inc., 552 So. 2d 288, 290 (Fla. Dist. Ct. App. 1989) (finding that where information on customer list was easy to obtain through advertisements, plaintiff was not entitled to trade secret protection); Hamer Holding Group, Inc. v. Elmore, 560 N.E.2d 907, 918-19 (Ill. App. Ct. 1990) (holding that a customer list is not a trade secret where it can be easily duplicated using a public telephone directory).

150 See, e.g., Standard Register Co. v. Cleaver, 30 F. Supp. 2d 1084, 1094-96 (N.D. Ind. 1998) (refusing to protect a customer list as a trade secret, but finding that employer has a protectable interest where employee's personal contacts and the development of a trusting relationship between a customer and a salesman is a key factor in securing business); Roto-Die Co. v. Lesser, 899 F. Supp. 1515, 152223 (W.D. Va. 1995) (preserving parts of a covenant preventing disclosure of confidential information and solicitation of plaintiff's employees despite non-existence of a trade secret); Chem-Trend Inc. v. McCarthy, 780 F. Supp. 458, 461 (E.D. Mich. 1991) (finding it appropriate to enjoin the wrongful use of knowledge of special needs of a customer and the price strategies and quotes for different products, even though this knowledge does not qualify as a trade secret); Osage Glass, Inc. v. Donovan, 693 S.W.2d 71, 74 (Mo. 1985) (en banc) (holding that a noncompete agreement may be enforced where employees have substantial customer contact, despite the nonexistence of a "secret customer list"); Cont'l Res. Corp. v. Schloz, 595 S.W.2d 396, 401 (Mo. Ct. App. 1980) (finding that although adaptations of business forms to meet employer's needs do not qualify as trade secrets, an employer may be protected where the employee is in a position to exert influence over the customer and entice the customer's business away from the employer). 
do. ${ }^{151}$

Courts that expand the legitimate interest test to include customer lists, do so because they view a firms' customers as the property of the firm and an essential element of the firm's good will. ${ }^{152}$ Such courts accord customer contact a high level of protection, permitting firms to control and constrain its use. ${ }^{153}$ However, the view that the employer has an exclusive property interest in customer contacts is in tension with the terms of the new employment relationship. As discussed in Part I of this Article, the new employment relationship involves promises by employers to provide employees with networking opportunities to interact and build contacts among suppliers and customers of the firm. ${ }^{154}$ At the same time, the new high performance work practices, such as TQM, dictate that employees should meet customers and become familiar with their needs. In today's workplace, employees are expected to become knowledgeable about, and interact with, a firm's customers in order to improve the firm's performance. Customer contact is promoted as a means to facilitate the employee's horizontal flexibility in the boundaryless workplace. Networking opportunities with customers are part of the implied promise of employability. The courts, by treating customer lists and knowledge of customer needs as the firm's exclusive property and a basis for enforcing restrictive covenants, are unwittingly undermining one of the most important terms of today's employment contract.

${ }^{151}$ In a review of cases seeking trade secret protection for customer lists under the Uniform Trade Secrets Act ("UTSA") as of 1987, attorneys Henry J. Silberberg and Eric G. Lardiere concluded that the UTSA provides less trade secret protection for customer contacts than the preexisting common law. As a result, they advised "people-oriented businesses" to impose covenants not to compete on employees who have significant contact with customers on the assumption that courts will enforce these clauses even though the information so protected is not a trade secret. See Silberberg \& Lardiere, supra note 143 , at $487,504-05$.

152 See Edmondson v. Am. Motorcycle Ass'n, 54 F. Supp. 2d 544, 550 (W.D.N.Y. 1999) (stating that "'[g]ood will' is a property right which consists of intangibles associated with favorable community relations and identification of business name... The development or improvement of customer relations is good will"), vacated in part 243 F.3d 537 (4th Cir. 2001); Carriage Hill Health Care, Inc. v. Hayden, No 96-101-SD, 1997 U.S. Dist. LEXIS 21755, at *12-*16 (D.N.H. Apr. 30, 1997) (finding that Carriage Hills's customer ratings and the histories of purchases were protectable trade secrets because they reflected levels of creative compilation and were not ascertainable from other sources); Morlife, Inc. v. Perry, 66 Cal. Rptr. 2d 731, 735-36 (Cal. Ct. App. 1997) (finding that "where the employer has expended time and effort identifying customers with particular needs or characteristics, courts will prohibit former employees from using this information to capture a share of the market"); see also Standard Register Co., 30 F. Supp. 2d at 1094-97 (refusing to protect a customer list as a trade secret, but enjoining competition because of employer's good will).

153 See Edmondson, 54 F. Supp. 2d at 550; Carriage Hill Health Care, Inc., 1997 U.S. Dist. LEXIS 21755, at *12-*16; Morlife, Inc., 66 Cal. Rptr. 2d at 735-36; see also Standard Register Co., 30 F. Supp. 2d at 1094-97 (refusing to protect a customer list as a trade secret, but enjoining competition because of employer's good will).

${ }^{154}$ See supra text accompanying notes 1-7. 


\section{b. Employer-Provided Training}

The second factor that courts have begun to use to justify enforcement of covenants not to compete is the presence of employer-provided training. Under the courts' traditional approach, if an employee's knowledge is not a trade secret, the knowledge belongs to the employee and its use cannot be restrained regardless of who paid for its acquisition..$^{155}$ Recently, however, courts have justified enforcing covenants on the ground that the employer paid for an employee's training to acquire skills and is thus entitled to prevent the employee from utilizing those skills on behalf of a competitor, even when there was no trade secret involved. ${ }^{156}$ The "who pays" factor in covenant cases is relatively new. A 1990 survey of 105 cases involving employment restrictive covenants, conducted by Peter Whitmore, did not find the presence of an employer's investment in training to be sufficiently significant to warrant discussion. ${ }^{157}$ Now, however, employer-provided training is a frequently cited rationale for enforcing noncompete covenants. ${ }^{158}$

Legal economists Paul Rubin and Peter Shedd have analyzed restrictive employment covenants in terms of the distribution of training costs and the incentives that training creates. They use Gary Becker's human capital model as their point of departure. ${ }^{159}$ Becker's model of employee training and human capital distinguishes two types of training-specific and general. ${ }^{160}$ "Specific" training is defined as training that has value only to the specific firm. "General" training, on the other hand, is training that

155 See Robert Unikel, Bridging the Trade Secret Gap: Protecting "Confidential Information" Not Rising to the Level of Trade Secrets, 29 LOY. U. CHI. L.J. 841, 867-75 (1998) (describing the current two-tiered approach, in which an employee's knowledge is classified either as general and thus not subject to judicial protection, or as a trade secret and entitled to judicial protection).

${ }^{156}$ See, e.g., Aero Kool Corp. v. Oosthuizen, 736 So. 2d 25, 26 (Fla. Dist. Ct. App. 1999) (finding that the Aero Kool Corporation had a legitimate business interest in the extensive specialized training in aircraft component repair that is provided to the defendant). Even in Texas, where the state supreme court has been reluctant to enforce covenants not to compete, the court has enforced covenants when the employer has provided the employee with training. See Hill v. Mobile Auto Trim, Inc., 725 S.W.2d 168, 171 (Tex. 1987), superseded by TEX. BUS. \& COM. CODE ANN. $§ 15.50$ to 15.51 (Vemon Supp. 2001).

${ }^{157}$ See Whitmore, supra note 9, at 524-25 \& n.243. Employer investment in training was one of fifteen variables clustered together with trade secrets, exposure to customer information, and geographic restriction included under the general heading "hardship to the employer." Id.

${ }^{158}$ See, e.g., Am. Express Fin. Advisors v. Scott, 955 F. Supp. 688, 692 (N.D. Tex. 1996); Weber v. Tillman, 913 P.2d 84, 91 (Kan. 1996); Overholt Crop Ins. Serv. Co. v. Bredeson, 437 N.W.2d 698, 703-04 (Minn. Ct. App. 1989); Nail Boutique, Inc. v. Church, 758 S.W.2d 206, 209 (Mo. Ct. App. 1988). See also Outsource Int'l, Inc. V. Barton, 192 F.3d 662, 671 (7th Cir. 1999) (Posner, J., dissenting); Aero Kool Corp., 736 So. 2d at 26; Hill, 725 S.W.2d at 171, superseded by TEX. BUS. \& COM. CODE ANN. $\S \S 15.50$ to 15.51 (Vernon Supp. 2001).

159 See Rubin \& Shedd, supra note 13, at 93-94.

${ }^{160}$ GaRy S. BECKER, Human CAPITAL: A THEoretical AND EMPIRICAL ANAlysis 19-26 (2d ed. 1975). 
has value to other firms either in that specific industry or in the general economy. ${ }^{161}$ Becker posits that employers will pay most of the costs of specific training because they benefit from providing this training which is, by definition, of value to them but not to other firms. ${ }^{162}$ Once they pay for specific training, employers will encourage employees to stay on the job long enough to make the employer's investment in the training worthwhile. ${ }^{163}$ Indeed, the firms' desire to recoup the costs of specific training is frequently cited to explain why employers establish internal labor markets and encourage long-term employment relationships in the first place. ${ }^{164}$

General training, on the other hand, enhances the labor market power of the employee because it makes her more valuable to other firms. Becker surmises that employers will not be willing to pay for general training because they have no way to ensure that the employee will remain on the job and use the training solely on the employer's behalf. ${ }^{165}$ Instead, the employee will self-finance general training by accepting lower wages. ${ }^{166}$

Rubin and Shedd adopt the Becker framework, but they modify Becker's model by positing that there are actually two types of general training. They claim that some general human capital consists of general skills, as well as knowledge that an employee is willing to finance through lower wages, while some consists of specialized trade secret information that is far too valuable and costly for an employee to self-finance. ${ }^{167}$ This latter type of information is not firm specific in Becker's typology because it is information that other firms would benefit from having. ${ }^{168}$ Rubin and Shedd claim that most employees obtain training in both types of general human capital-general training that they self-finance and trade secrets that the employer finances. ${ }^{169}$

Rubin and Shedd posit that an employer will be willing to finance the acquisition of general human capital of the latter type so long as the employer can protect it with a restrictive covenant that prevents an employee from opportunistically obtaining valuable knowledge and then leaving and using it on behalf of a competitor. ${ }^{170}$ If courts do not enforce such covenants, Rubin and Shedd contend, employers will be discouraged from de-

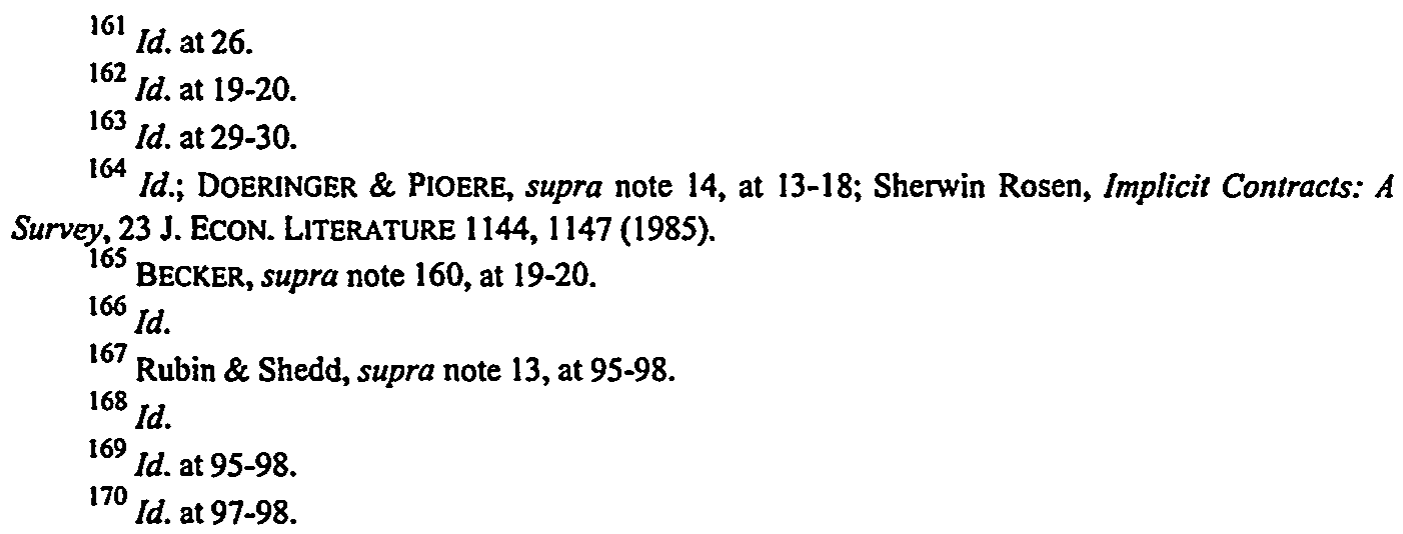


veloping this type of information or will be forced to utilize it in a guarded and inefficient manner. ${ }^{171}$ Thus, they conclude, it is efficient for a court to enforce a restrictive covenant when doing so encourages the development of specialized trade secret information.

However, Rubin and Shedd also point out that if there is a restrictive covenant, employees are vulnerable to opportunistic behavior by employers. ${ }^{172}$ Specifically, there is a danger that employers might use a covenant to restrain the employee from using not merely the trade secret that the employer paid for, but also the general training that the employee selffinanced. ${ }^{173}$ Furthermore, Rubin and Shedd argue that, as a practical matter, it is impossible to draft a covenant that distinguishes between the two types of general human capital. ${ }^{174}$ Thus, they argue that to enforce all covenants would be inefficient, just as it would be inefficient to enforce none of them. ${ }^{175}$ They conclude that it is appropriate for courts to restrict enforcement of covenants to information that comprises a trade secret. ${ }^{176}$ They counsel courts to determine what information is within the covenant on a case-by-case basis, and to only enforce covenants involving training in trade secrets or confidential information provided by the employer. ${ }^{177}$

Rubin and Shedd's application of Becker's human capital model argues for a return to the view that restrictive covenants should only be enforced to protect knowledge that involves a trade secret. Only in those cases can it be ensured that the employer has paid for the acquisition of knowledge so protected. They claim that their analysis explains why noncompete covenants are found primarily in industries and occupations in which specialized training is important. ${ }^{178}$ They also use their analysis to explain customer list cases. ${ }^{179}$ When a customer list involves specialized knowledge that was expensive to obtain, Rubin and Shedd argue, it is a type of specialized general human capital that is a legitimate subject of a covenant. ${ }^{180}$

Under Rubin and Shedd's analysis, when asked to enforce a noncompetition covenant, the court's function is to ascertain whether the covenant is limited to protecting knowledge for which an employer paid. ${ }^{181}$ When a

\footnotetext{
${ }^{171}$ Id.

172 Id. at 98.

${ }^{173}$ See id.

${ }^{174}$ Id.

175 Id.

176 Id. at 98.

177 Id. at 99.

178 Id.

${ }^{179}$ Id. at 102-04.

180 Id. at 104.

${ }^{181}$ See id. at $98-99$.
} 
covenant is properly limited in its scope, the court should enforce it to prevent the employee from appropriating general knowledge that the employer did not intend to impart for the employee's own use. They propose that by limiting enforcement of noncompete covenants to trade secrets or other specialized knowledge, courts can best approximate this efficient result. ${ }^{182}$

While Rubin and Shedd's analysis makes sense in theory, it must be applied in light of the new employment relationship. Today it is more difficult than before to ascertain when an employer or when an employee has paid for the acquisition of certain knowledge. As seen in Part I, today's employers often promise to provide general training as part of the new employment relationship. There is a great deal of empirical evidence to suggest that in today's labor market, many employers pay for general training and skill development for at-will employees. ${ }^{183}$ This evidence is consistent with one of the most important terms of the new psychological contractthe employers' promise of general training and employability security in exchange for employee motivation, commitment, and OCB. Employers also promise to provide general training in order to attract applicants. Thus, many firms offer to pay for some types of employee education so as to induce recruitment.

When an employer has promised to give an employee skill development and general knowledge as part of the employment deal, then it cannot be said that the employer has paid for its acquisition. Nor can it be assumed that the employer intended to preclude the employee from using knowledge for her own advantage. Rather, when such promises are present, the employees have paid for the training, not with reduced wages in the Gary Becker sense, but with increased commitment, OCB and acceptance of high performance work practices. Hence, when human capital development is part of what an employee is promised in the employment deal, it must then be concluded that the resulting human capital so obtained belongs to the employee.

There are occasions in which an employer provides training, not as part of a psychological contract to elicit OCB or to attract high quality applicants, but merely to give employees skills to perform specific work tasks. In cases in which a firm is only willing to provide training if it can realize a short-run profit from the training investment, it can protect that interest

\section{Id. at 110.}

183 See Daron Acemoglu \& JORn-Steffen PischKe, Beyond BeCKer: Training IN IMPERFECT LABOR MARKETS 4-5 (Nat'l Bureau of Econ. Research, Working Paper No. 6740, 1998) (giving examples of firms bearing the full costs of general training); John M. Barron et al., Do Workers Pay for On-the-Job Training?, 34 J. HUM. ResouRCES 235, 250 (1999); Mark A. Loewenstein \& James R. Spletzer, General and Specific Training: Evidence and Implications, 34 J. HUM. RESOURCES 710, $729-$ 31 (1999). See generally RONALD G. EHRENBERG \& ROBERT S. SMITH, MODERN LABOR ECONOMICS: THEORY AND PUBLIC POLICY 162-66 (6th ed. 1997) (presenting empirical studies suggesting that employers bear much of the costs of on-the-job training, including general training). 
without resort to a broad covenant not to compete. An employer can request that the employee agree to repay the training costs if the employee departs before the employer is able to recoup the training costs. ${ }^{184}$ However, to be enforceable, a training repayment agreement must be written narrowly. ${ }^{185}$ If a training repayment agreement only requires repayment in circumstances in which the employee goes to work for a competitor, then courts will view the agreement as a disguised covenant not to compete and will subject it to the same scrutiny they apply to covenants not to compete. ${ }^{186}$ For example, in Heartland Securities Corp. v. Gerstenblatt, the court stated:

The fact that Heartland will forgive the entire repayment of training costs if the employee does not compete with the company in any way for a four year period from the start of his employment further supports this Court's finding that the true purpose and intent of the provision is to discourage an employee from leaving the company. If the refund of training costs provision was intended merely to recoup training costs, those costs to the company should be the same no matter what the employee does after leaving Heartland. ${ }^{187}$

Similarly, if a training repayment agreement calls for repayment in amounts that are not reasonably related to the actual training costs, courts will treat it as a penalty provision and refuse enforcement. ${ }^{188}$ However, if an employer requires employees to sign a clear and narrowly written repayment agreement that applies only to the cost of training provided, is not economically excessive, and is triggered by departure before a specified date, regardless of the employee's subsequent employment, it is enforceable. ${ }^{189}$ When an employee accepts a narrowly crafted training repayment agreement, she is on notice that training is not an implicit term of the employment contract, but rather something that she is required to pay for by

${ }^{184}$ See Anthony W. Kraus, Repayment Agreements for Employee Training Costs, 44 LAB. L.J. 49, 51 (1993). But see Rachel Amow-Richman, Bargaining for Loyalty in the Information Age, 80 OR. L. REV. (forthcoming Feb. 2002) (questioning whether such retraining agreements can be written with sufficient particularity to avoid the pitfalls of a noncompetition covenant) (manuscript on file with the Connecticut Law Review).

${ }^{185}$ See Kraus, supra note 184, at 50.

${ }^{186}$ See Brunner v. Hand Indus., 603 N.E.2d 157, 159-60 (Ind. Ct. App. 1992).

${ }^{187}$ Heartland Sec. Corp. v. Gerstenblatt, No. 99 CIV 3694, 2000 U.S. Dist. LEXIS 3496, at *19 (S.D.N.Y. Mar. 22, 2000).

${ }^{188}$ See id.; Brunner, 603 N.E.2d at 159-60; Heder v. City of Two Rivers, 149 F. Supp. 2d 677, 694 (E.D. Wis. 2001).

${ }^{189}$ See, e.g., Milwaukee Area Joint Apprenticeship Training Comm. for the Elec. Indus. v. Howell, 67 F.3d 1333, 1339 (7th Cir. 1995). 
her continued employment. ${ }^{190}$ Under these circumstances, enforcement of such an agreement, unlike enforcement of a broad covenant not to compete, does not undermine her psychological contract.

In sum, courts should take the implicit terms of the new psychological contract into account when deciding whether or not to enforce covenants not to compete. When employers argue for enforcement of covenants not to compete on the grounds that the employer paid for the training, courts should inquire as to whether the promise of general training was expressly or tacitly part of a larger employment deal. If it was, then they should not restrain employees from subsequently using the knowledge so obtained.

\section{B. Trade Secrets and Inevitable Disclosure}

Employers can obtain judicial protection for specialized knowledge, even without a restrictive covenant, when the knowledge consists of a trade secret. However, a trade secret is not a self-defining term. Different courts, at different times, have used different definitions of what constitutes a trade secret. For example, courts differ in their determination of whether negative knowledge qualifies as a trade secret. ${ }^{191}$ Obviously, the broader the definition of trade secret used, the more protection an employer has for knowledge about its products and operations.

Until the late 1980s, trade secrets were protected under the common law with guidance from the Restatement of Torts, prepared by the American Law Institute. At that time, the Restatement of Torts defined a trade secret as "any formula, pattern, device or compilation of information which is used in one's business and which gives [one] an opportunity to obtain an advantage over competitors who do not know or use it."192 Pursuant to this approach, trade secret protection was available for specific inventions, formulas, devices, and other technical information that was only known to a firm but that would be valuable in the hands of a competitor. The Restatement of Torts's definition of a trade secret, however, did not extend to general business information, market plans, or customer contacts. ${ }^{193}$

${ }^{190}$ See Gillian Lester, Restrictive Covenants, Employee Training, and the Limits of TransactionCost Analysis, 76 IND. L.J. 49, 75-76 (2001) (advocating statutory provisions permitting training repayment contracts subject to an explicit statutory cap).

191 Compare Novell Inc. v. Timpanogos Res. Group, 46 U.S.P.Q.2d (BNA) 1197, 1216-17 (D. Utah 1998) (using negative knowledge to justify applying inevitable disclosure doctrine), with EarthWeb v. Schlack, 71 F. Supp. 2d 299, 315 (S.D.N.Y. 1999) (rejecting the argument that knowledge of a product's deficiencies is a trade secret).

192 RESTATEMENT OF TORTS $\S 757 \mathrm{cmt}$. b (1934). This section was not included in the Restatement (Second) of Torts published in 1979.

${ }^{193}$ See, e.g., AMP, Inc. v. Fleischhacker, 823 F.2d 1199, 1203-04 (7th Cir. 1987) (stating that there is no trade secret protection for general confidential business information, including information about business and strategic planning, new product development, manufacturing processes, cost and capacity, financial information, budget information, or marketing and customer information). 
In the past fifteen years, the definition of a trade secret has expanded dramatically. In 1985, the National Conference of Commissioners on Uniform State Law amended its Uniform Trade Secrets Act ("UTSA") include a broader definition of trade secrets. Under the UTSA, a trade secret is defined as information that (1) "derives independent economic value, actual or potential, from not being generally known ... and not being readily ascertainable" and that (2) an employer uses reasonable efforts to keep secret. ${ }^{195}$ This definition extends trade secret protection beyond technical information to all commercially valuable information. As of 2001 , forty-three states had adopted the definition of trade secrets recommended in the UTSA. ${ }^{196}$

Also, in 1995, another committee of the American Law Institute drafted the Restatement (Third) of Unfair Competition, which also adopted an expansive definition of trade secrets. ${ }^{197}$ The Restatement of Unfair Competition ("RUC") defined a trade secret as: "any information that can be used in the operation of a business or other enterprise and that is sufficiently valuable and secret to afford an actual or potential economic advantage over others." ${ }^{198}$ By focusing on economic value rather than specific concrete technical innovations, the UTSA and RUC approaches make the definition of trade secret almost infinitely expandable. The modern trend has also generated great uncertainty in practice.

As courts expand the types of information they call trade secrets, it becomes increasingly difficult for an employee to avoid learning them. Even an employee who does not want to be exposed to his employer's trade secrets has no way to know which information that he learns on a job might later be the subject of a successful claim of protected trade secret status. When such an employee changes jobs, he is at risk of a lawsuit for misappropriation.

The expansion in the definition of trade secrets is closely linked to the controversial doctrine of inevitable disclosure. The doctrine of inevitable disclosure became prominent in 1995, in the case of Pepsico, Inc. v. Redmond. ${ }^{199}$ In that case, the Seventh Circuit Court of Appeals enjoined William Redmond, a Pepsico, Inc. ("Pepsico") employee, from working for the Quaker Oats Company ("Quaker"), the maker of Gatorade, a competitor,

194 UNIF. TRADE SECRETS ACT §§ 1(4)(i)-(ii), 14 U.L.A. 463 (1990).

195 Id.

${ }^{196}$ William Schaller, Jumping Ship: Legal Issues Relating to Employee Mobility in High Technology Industries, 17 LAB. LAW 25, 32 (2001) (noting that forty-three states have adopted some version of the UTSA).

197 RESTATEMENT (THIRD) OF UNFAIR COMPETITION $\$ 39$ (1995).

198 Id. The RESTATEMENT (THIRD) OF UNFAIR COMPETITION also expands the remedies available to employers to protect their confidential information.

${ }^{199} 54$ F.3d 1262 (7th Cir. 1995). 
even though Redmond's employment contract did not contain a covenant not to compete and despite the fact that Pepsico had no trade secret at risk. ${ }^{200}$ The court reasoned that Redmond had valuable knowledge about the Pepsico operations, including knowledge about its business and marketing plans, that he would inevitably disclose in his new job. ${ }^{201}$ As a result, Redmond was enjoined from accepting a position with Quaker to do the type of work that he was most qualified to do. ${ }^{202}$ The Pepsico decision has been widely criticized, yet it remains good law in many jurisdictions. ${ }^{203}$

The doctrine of inevitable disclosure is a natural outgrowth of employers' aggressive efforts to restrict employees' use of knowledge. Yet, there is a deep-seated conflict between the new employment relationship and the inevitable disclosure doctrine. In today's workplace, employees are expected to participate in many aspects of the firm, develop knowledge about the firm's overall operation, create cross-departmental links, and engage in a wide variety of tasks. Flexibility and cross-utilization are essential elements of the new work practices. Furthermore, employees are expected to interact with networks and to develop knowledge about business practices, customers, competitors, and the larger context of the firm. Indeed, as discussed above, compensation practices often reward such knowledge. The more an employee knows, the more valuable she is to her firm, yet the more she is in danger that she might have knowledge that she would "inevitably" disclose. ${ }^{204}$

In addition, the new employment relationship requires employees to construct their own boundaryless careers. Rather than promising job security, employers encourage employees to depart and to seek employment in related firms. If employers expect employees to network beyond the boundary of the firm, it would be a bitter irony if they were not free to enjoy the benefits of the contacts and opportunities that such networks provide. They should not find themselves unemployed and unemployable when they seek to further their careers.

\footnotetext{
200 Id. at 1264,1268 .

201 Id. at 1270.

202 See id. at 1272.
}

${ }^{203}$ See Lumex, Inc. v. Highsmith, 919 F. Supp. 624, 633-34 (E.D.N.Y. 1996) (differentiating the facts in that case from those in Pepsico); Cardinal Freight Carriers, Inc. v. J.B. Hunt Transp. Servs., 987 S.W.2d 642, 643-44 (Ark. 1999) (citing Pepsico as good law). But see Bayer Corp. v. Roche Molecular Sys., 72 F. Supp. 2d 1111, 1120 (N.D. Cal. 1999) (noting that California does not recognize the doctrine of inevitable disclosure because to do so would create a "de facto covenant not to compete," which is unenforceable in California). For a critical discussion of the Pepsico decision, see Alan Hyde, The Wealth of Shared Information (unpublished manuscript, on file with the author); see also Milton E. Babirak, The Virginia Uniform Trade Secrets Act, 5 VA. J.L. \& TECH. 15, 25 (2000) (criticizing Pepsico); see generally Jay L. Koh, From Hoops to Hard Drives: An Accession Law Approach to the Inevitable Misappropriation of Trade Secrets, 48 AM. U. L. REv. 271, 281-85 (1998) (summarizing positions in debates over the inevitable misappropriation doctrine).

${ }^{204}$ Pepsico, 54 F.3d at 1269. 
Under current trends, the most successful employee in the new workplace is the one who is most at risk from the inevitable disclosure doctrine. The more successful an employee is on the employer's own terms, the more likely she is to be penalized when she departs. Courts have expanded their definition of trade secrets and restricted disclosure of knowledge that does not rise to the level of a trade secret, at the same time that employees are expected to, and rewarded for, gaining as much knowledge as possible about the overall operation of their firms. Successful employees will be frozen out of subsequent employment opportunities in their field. In this area, the law is clearly out of step with business practice.

\section{THE ROLE OF IMPLICIT CONTRACTS IN EMPLOYMENT REGULATION}

It has been argued above that courts should recognize the implicit promises in the employment relationship when deciding whether or not to enforce restrictive covenants and in determining the scope of trade secret protection. ${ }^{205}$ Employment contracts are famously incomplete, particularly when they are at-will and are made pursuant to an oral agreement. It is well understood that employment contracts embody shared understandings and mutually agreed-upon terms that are not a part of the formal contractual apparatus. Hence, it is common for courts to take implicit understandings into account when determining the rules for employment regulation.

Two examples are presented below to demonstrate that courts can and do take implicit understandings into account when determining the rules for employment regulation. These examples, selected for their relevance to the issues under discussion herein, concern the refusal of the English courts to enforce restrictive covenants in the sixteenth and seventeenth century and the trend in some United States courts to modify the at-will employment relationship in the 1970 s and 1980 s.

\section{A. The Origin of Judicial Attitudes Toward Restrictive Covenants}

The current disputes about ownership of human capital are analogous to disputes in the sixteenth and seventeenth centuries about employee training and mobility. ${ }^{206}$ The historic refusal of the English courts to enforce employment covenants not to compete arose from the ancient common law courts' desire to enforce the unwritten, customary terms of guild apprenticeship arrangements and thus to prevent masters from circumventing them. ${ }^{207}$

${ }^{205}$ See discussion supra Part III.

${ }^{206}$ See infra text accompanying notes 208-19 (discussing disputes in the sixteenth and seventeenth centuries about employee training and mobility).

${ }^{207}$ See Harlan M. Blake, Employee Agreements Not to Compete, 73 HARV. L. REV. 625, 631-37 (1960). 
The medieval European craft guilds had apprenticeship systems that provided master craftsmen with a labor force while at the same time serving as a system of technical training for young men. ${ }^{208}$ In the guild system, some of the obligations of both master and apprentice were provided by a contract, termed an indenture, but most were based on custom. ${ }^{209}$ Later, statutes were enacted to set some apprenticeship terms. ${ }^{210}$ For example, in 1563, the Statute of Apprentices set the duration of apprenticeships at seven years. ${ }^{211}$ Disputes arose in the fifteenth and sixteenth centuries because masters wanted to take on more and more apprentices and bind them for longer periods of time. ${ }^{212}$ As a result, there was a large increase in the number of journeymen seeking to become craftsmen, something the established craftsmen wanted to prevent. ${ }^{213}$ The master craftsmen wanted the cheap labor that apprentices provided without having to endure competition from the resulting increase in the numbers of craftsmen. Hence, the master craftsmen tried to restrict the number of future craftsmen by making entrance examinations more difficult and by charging exorbitant entrance fees. ${ }^{214}$ Some craftsmen also extracted promises from their apprentices and journeymen not to assume the role of craftsmen upon when their traditional term expired. ${ }^{215}$ These were early forms of employment covenants not to compete.

Because the guild system was a deep part of society's social and moral fabric, there was general outrage against unethical masters who tried to subvert the customary rules of apprenticeship by restricting apprentices' ability to practice their craft. ${ }^{216}$ Statutes were enacted to protect apprentices. $^{217}$ In the sixteenth and seventeenth centuries, some apprentices brought legal actions to challenge post-apprenticeship restraints contained in the indentures, and the courts held that such restraints were void. ${ }^{218}$ According to legal historian Harlan Blake, "these cases represent reactions by the judges against erosions in the customs of the guilds by aggressive craftsmen, [and] ... [t] hey show judicial support of the customary concepts of 'fair' commercial activity of the late medieval period . ..."219 Thus, in

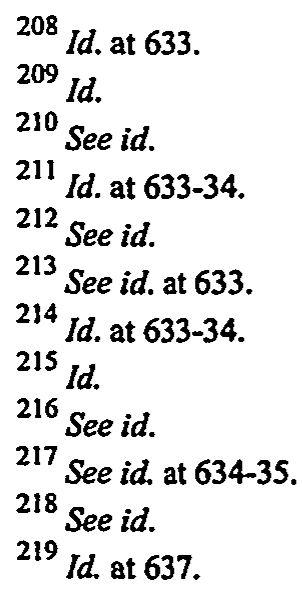


the seventeenth century, courts became suspicious of covenants not to compete because they viewed them as attempts by employers to breach customary understandings of the terms of the employment relationship.

\section{B. Judicial Modification of the At-Will Regime in the $1980 \mathrm{~s}$}

Closer to home, today's problem of employer tendency to breach psychological contracts for training and networking finds a parallel in the judicial developments in the at-will employment area in the 1980s. In the 1970 s and 1980s, commentators and employees were bristling at the unfairness of the at-will employment doctrine. ${ }^{220}$ Employees who had been at their jobs for long periods and held what they believed to be implicit contracts for long-term job security were shocked to find themselves dismissed or down-sized. ${ }^{221}$ This trend fueled the movement within many state courts, and some state legislatures, to modify the at-will rule to bring it into congruence with the implicit psychological contracts of the then-dominant employment relationship-the internal labor market model of long-term job security. ${ }^{222}$ Some courts in the 1980s recognized that employers often gave employees an implicit promise of long-term job security in exchange for commitment and loyalty. ${ }^{223}$ Where such an implicit promise had been given, some courts enforced the implicit contract by imposing a just cause restriction on the employer's power to dismiss. ${ }^{224}$

220 Claudia E. Decker, Comment, The At-Will Doctrine: A Proposal to Modify the Texas Employment Relationship, 36 BAYLOR L. REV. 667, 684-86 (1984); Donald G. Kempf, Jr. \& Roger L. Taylor, Wrongful Discharge: Historical Evolution, Current Developments and a Proposed Legislative Solution, 28 SAN DIEGO L. Rev. 117, 120-123 (1991). See generally Lawrence E. Blades, Employment at Will vs. Individual Freedom: On Limiting the Abusive Exercise of Employer Power, 67 COLUM. L. REV. 1404 (1967) (advocating change in at-will rule); Clyde W. Summers, Individual Protection Against Unjust Dismissal: Time for a Statute, 62 VA. L. REv. 481 (1976) (same).

221 Pauline T. Kim, Bargaining with Imperfect Information: A Study of Worker Perceptions of Legal Protection in an At-Will World, 83 CORNELL L. REV. 105 (1997); Pauline T. Kim, Norms, Learning, and Law: Exploring the Influences on Workers' Legal Knowledge, 1999 U. ILL. L. REV. 447, 451452 (1999).

222 For a few of the numerous articles recounting the change from at-will employment to just cause regimes in many state courts and one state legislature, see generally Jeanne Duquette Gorr, The Model Employment Termination Act: Fruitful Seed or Noxious Weed?, 31 DUQ L. REV. 111 (1992); William B. Gould IV, Job Security in the United States: Some Reflections on Unfair Dismissal and Plant Closure Legislation from a Comparative Perspective, 67 NEB. L. REV 28, 30 (1988); William B. Gould IV, Stemming the Wrongful Discharge Tide: A Case for Arbitration, 13 EMPL. REL. L.J. 404, 409-10 (1987-88); Joan M. Krauskopf, Employment Discharge: Survey and Critique of the Modern AtWill Rule, 51 UMKC L. REv. 189 (1983); Comelius J. Peck, Penetrating Doctrinal Camouflage: Understanding the Development of the Law of Wrongful Discharge, 66 WASH. L. REV. 719 (1991); Theodore J. St. Antoine, A Seed Germinates: Unjust Discharge Reform Heads Toward Full Flower, 67 NEBR. L. Rev. 56 (1988); Note, Protecting At-Will Employees Against Wrongful Discharge: The Duty to Terminate Only in Good Faith, 93 HARV. L. REV. 1816 (1980).

${ }^{223}$ Pugh v. See's Candies, Inc., 171 Cal. Rptr. 917 (Cal. Ct. App. 1981); Toussaint v. Blue Cross \& Blue Shield, 292 N.W.2d 880, 895 (Mich. 1980).

${ }^{224}$ See, e.g., Fletcher v. Wesley Med. Ctr., 585 F. Supp. 1260, 1263-64 (D. Kan. 1984); Pugh, 
Since the early 1990s, there have been fewer disputes over at-will employment despite continuing lay-offs and workforce churning. ${ }^{225}$ In part, this is because many employees no longer have psychological contracts for long-term employment. With the new employment relationship, implicit promises of job security are not so widespread. In fact, to avoid ambiguity, many employers now make explicit statements to employees, orally and in writing, that the employment relationship is at-will and that there are no implicit promises of long-term job security. ${ }^{226}$

Today, the problem of unfairness for individual employees is different than it was in the 1980s. As shown in Part I, some of the most important terms of the new employment relationship are that employers will provide employees with training, skill development, networking opportunities, and general human capital development. Under the new employment relationship, the problem is no longer employer breaches of implicit promises of job security, but rather employer breaches of the other promises implicit in the employment relationship. Networking, training, and lateral mobility are a fundamental aspect of today's employment system. Yet, it is often in the interest of individual employers to breach these new psychological contracts, just as it was at times in the interest of employers to breach the old psychological contracts through unjust dismissals.

\section{Enforcing the Psychological Contract of the New Employment Rela- tionship}

The lessons from the past demonstrate that courts can and should take psychological contracts and implicit understandings of the employment relationship into account when regulating the employment relationship. Thus, they should reassess the trend toward giving ever wider scope to covenants not to compete by recognizing that under the new employment contract, employees have been promised not only training, upskilling, and networking, but also the ability to use their newly acquired skills in subsequent employment. While individual employers may have an incentive to offer these benefits and then renege, the courts should not support them in doing so. For firms to remain dynamic in today's marketplace, they need to promote citizenship, commitment, creativity, and effort in their work-

171 Cal. Rptr. at 921, 927,overruled in part on other grounds by Guz v. Bechtel Nat'l, Inc., 8 P.3d 1089 (Cal. 2000); Salimi v. Farmers Ins. Group, 684 P.2d 264, 265 (Colo. Ct. App. 1984); Toussaint, 292 N.W.2d at 892; Woolley v. Hoffman-La Roche, Inc., 491 A.2d 1257, 1268 (N.J. 1985); Thompson v. St. Regis Paper Co., 685 P.2d 1081, 1089 (Wash. 1984).

${ }^{225}$ See, e.g., Louis Uchitelle, Pink Slip? Now It's All in a Day's Work, N.Y. TIMEs, Aug. 5, 2001, $\S 3$, at 1 (noting that despite a new round of layoffs, "the usual protests and anger are largely missing").

${ }^{226}$ See Robert F. Wayland, Joan M. Clay \& Stephen L. Payne, Employment-at-Will Statements: Perceptions of Job Applicants, 14 INT'L J. MANPOWER 2225-26 (reporting on surveys that found that more than sixty percent of firms expressly state their right to terminate employment at-will on job applications or in employee handbooks). 
force. To do that, firms need to honor the psychological contracts they offer. If they do not do so voluntarily out of short-term, opportunistic motives, courts should force them to do so by preventing their efforts to renege. ${ }^{227}$

\section{CONCLUSION.}

In conclusion, I have argued that courts should address today's disputes over ownership of human capital in the same spirit as their predecessors have done. Just as courts in the seventeenth century enforced customary and tacit understandings, today's courts should develop an approach to human capital cases that prevents employers from violating the tacit understandings of today's employment contract. When forced to decide who owns the employees' general human capital, courts should factor the implicit terms of the new psychological contract into their determination. Thus, courts should adopt a narrow definition of trade secrets, limit enforcement of noncompete covenants to the protection of trade secrets narrowly defined, reject the doctrine of inevitable disclosure, and thereby give employees broad rights to acquire, retain, and deploy their human capital.

${ }^{227}$ Recently, AnnaLee Saxenian, Ronald Gilson and Alan Hyde, in separate works, made a similar but slightly different argument. They each have argued that the success of Silicon Valley as a highgrowth agglomeration economy is the result of California's refusal to enforce covenants not to compete. See anNalee SaXenian, Regional Advantage: Culture and Competition in Silicon VALLEY AND ROUTE 128 (1994) (comparing the industrial districts of Califomia's Silicon Valley and Massachusetts's Route 128); Gilson, supra note 86, at $622-24$ (discussing California's reluctance to recognize the inevitable disclosure doctrine); Alan Hyde, The Wealth of Shared Information: Silicon Valley's High-Velocity Labor Market, Endogenous Economic Growth, and the Law of Trade Secrets (Sept. 1998) (unpublished manuscript, on file with the Connecticut Law Review). They contend that it is in the public interest for employees to move freely between firms, taking their knowledge with them, and therefore courts should adopt a permissive attitude toward employee mobility and a restrictive approach toward both covenants not to compete and trade secret protections. SAXENIAN, supra at 128; Gilson, supra note 91 , at 622-24. 